\title{
Measurements of the double layer capacitance for electrodes in supercritical $\mathrm{CO}_{2} /$ acetonitrile electrolytes.
}

\author{
P. N. Bartlett* and D. A. Cook \\ Chemistry, University of Southampton, Southampton, SO17 1BJ, UK \\ *P.N.Bartlett@ soton.ac.uk
}

\begin{abstract}
Electrochemical impedance measurements were made in the single supercritical phase of $\mathrm{CO}_{2}$ with 11 wt \% acetonitrile as the co-solvent at temperatures and pressures between 306 and $316 \mathrm{~K}$ and 15.5 and 20.2 MPa over the potential range from -0.45 to $+0.75 \mathrm{~V}$ vs. Pt. Gold, platinum and glassy carbon electrodes were studied together with the effects of electrolyte concentration for $\left[\mathrm{NBu}_{4}{ }_{4}\right]\left[\mathrm{BF}_{4}\right]$. Two other electrolytes, $\left[\mathrm{NBu}_{4}{ }^{n}\right]\left[\mathrm{B}\left\{3,5-\mathrm{C}_{6} \mathrm{H}_{3}\left(\mathrm{CF}_{3}\right)_{2}\right\}_{4}\right]$ and $\left[\mathrm{NMe}_{4}\right]\left[\mathrm{BF}_{4}\right]$, were also studied. We find that the impedance data can be described by a simple RC equivalent circuit where the uncompensated solution resistance is independent of the electrode potential and is consistent with earlier measurements for the electrolyte conductivity. The results for the double layer capacitance can be described by a simple Helmholtz layer model and are very similar to those found for similar electrolytes in non-aqueous solvents such as propylene carbonate. For glassy carbon the double layer capacitances show a parabolic like potential dependence which we attribute to the lower density of states near the Fermi level.
\end{abstract}

\section{Introduction}

The charge distribution at the metal/electrolyte interface has a fundamental effect on interfacial processes and, specifically, on the rates of interfacial electron transfer reactions[1]. Models are well developed for conventional metal/electrolyte solution interfaces with descriptions in terms of the classical Helmholtz, Gouy-Chapman, and Stern Triple layer models [2] based originally in classical experimental studies of the mercury/sodium fluoride system. These models are supported by extensive experimental studies and modelling for aqueous solutions and for high dielectric organic solvents such as acetonitrile. Similar models have been used to describe the semiconductor/electrolyte and liquid/liquid junctions[3,4]. Most recently intensive attention has turned to studies of the metal/ionic liquid interface where simple Gouy-Chapman models are clearly inappropriate because of the high ion density $[5,6]$.

In contrast, data on the metal/supercritical fluid electrolyte interface are barely existent. Nevertheless the charge distribution is crucial for understanding the kinetics of redox reactions and electrodeposition studies. Electrochemistry in supercritical fluids has received attention for applications in electroanalysis[7], electrosynthesis [8-10], electrochemical reduction of $\mathrm{CO}_{2}[11,12$ ], electrodeposition[13-15], and for energy conversion[16]. Abbott and Eardley [17] appear to be the first authors to report double layer capacitance measurements in a polar supercritical fluid. They studied supercritical difuloromethane containing $20 \mathrm{mM}$ tetrabutylammonium tetrafluoroborate at platinum electrodes at $363 \mathrm{~K}$ and three pressures (13.5, 16 and $26 \mathrm{MPa}$ ). Based on their results they concluded that at the lower pressures, where the dielectric constant for the solvent was lower $(\varepsilon=8.5$ 
and 8.1), the double layer structure can be entirely described by the Helmholtz model whereas at the highest pressure, where the dielectric constant is higher $(\varepsilon=9.5)$, there were clear anodic and cathodic capacitance humps interpreted as evidence for a contribution from the diffuse double layer The results at high pressure were similar to those of Abbott and Harper [18] for quaternary ammonium electrolytes in organic solvents of low $(\varepsilon<10)$ dielectric. Abbott and Harper also studied the double layer capacitance for long chain quaternary ammonium electrolytes in supercritical $\mathrm{CO}_{2}$ [19]. Again, under the low dielectric condition for supercritical $\mathrm{CO}_{2}(\varepsilon=1.8)$ they found Helmholtz like behaviour with the double layer capacitance only very weakly dependent on the electrode potential.

In this paper we present the first results for the study of the double layer capacitance for supercritical $\mathrm{CO}_{2}$ /acetonitrile mixtures. Addition of acetonitrile $\left(\mathrm{CH}_{3} \mathrm{CN}\right)$ as a polar co-solvent increases the effective dielectric constant for the fluid and hence the solubility of electrolytes and the solution conductivity[20]. Supercritical $\mathrm{CO}_{2} / \mathrm{CH}_{3} \mathrm{CN}$ has been used in our group for the electrodeposition of both copper [14] and silver [15] and Toghill et al. [21] recently studied voltammetry for decamethylferrocene in supercritical $\mathrm{CO}_{2} / \mathrm{CH}_{3} \mathrm{CN}$. We have studied the double layer capacitance for supercritical $\mathrm{CO}_{2} / \mathrm{CH}_{3} \mathrm{CN}$ mixtures containing $2.1 \mathrm{M} \mathrm{CH}_{3} \mathrm{CN}(\sim 11 \mathrm{wt} \%)$ at platinum, gold and glassy carbon electrodes at constant density over the range 306 to $316 \mathrm{~K}$ and associated pressures from 15.5 to $20.2 \mathrm{MPa}$, and electrolyte concentrations from 6 to $30 \mathrm{mM}$. These represent the typical conditions appropriate to obtain a single supercritical phase with reasonable conductivity that is appropriate for electrodeposition. Results for three electrolytes, $\left[\mathrm{NBu}_{4}{ }^{n}\right]\left[\mathrm{B}\left\{3,5-\mathrm{C}_{6} \mathrm{H}_{3}\left(\mathrm{CF}_{3}\right)_{2}\right\}_{4}\right],\left[\mathrm{NBu}_{4}{ }^{n}\right]\left[\mathrm{BF}_{4}\right]$ and $\left[\mathrm{NMe}_{4}\right]\left[\mathrm{BF}_{4}\right]$, are presented. This represents the most extensive study of the double layer capacitance of and supercritical fluid system presented to date.

\section{Experimental}

Acetonitrile $\left(\mathrm{CH}_{3} \mathrm{CN}\right.$ HPLC grade, Rathburn) was distilled over calcium hydride and handled under inert atmosphere. Tetrabutylammonium tetrafluoroborate and tetramethylammonium tetrafluoroborate $\left(\left[\mathrm{NBu}_{4}{ }^{n}\right]\left[\mathrm{BF}_{4}\right]\right.$ and $\left[\mathrm{NMe}_{4}\right]\left[\mathrm{BF}_{4}\right], \geq 99$ pure, Sigma Aldrich) were used without further purification, but were stored either in a glove box or desiccator before experiments. $\left[\mathrm{NBu}_{4}{ }^{n}\right]\left[\mathrm{B}\left\{3,5-\mathrm{C}_{6} \mathrm{H}_{3}\left(\mathrm{CF}_{3}\right)_{2}\right\}_{4}\right]$ was synthesised and purified as described elsewhere[13, 20]. Carbon dioxide (99.999\% SCF grade, BOC) was used without further purification.

The cell used for the electrochemistry was a 2-piece stainless steel construction. The bottom part has a $10 \mathrm{~mL}$ well (that constitutes the working volume when assembled) and the top has $7 \mathrm{x}$ 1/16" female, SSI type fittings (through which electrodes, thermocouples and tubing could be sealed into the cell) and 1 unique safety valve. The 2 pieces are fitted together using a disposable elastomeric O-ring and a clamp that is locked in place. Figure 1 shows the cell and position of the electrodes. 


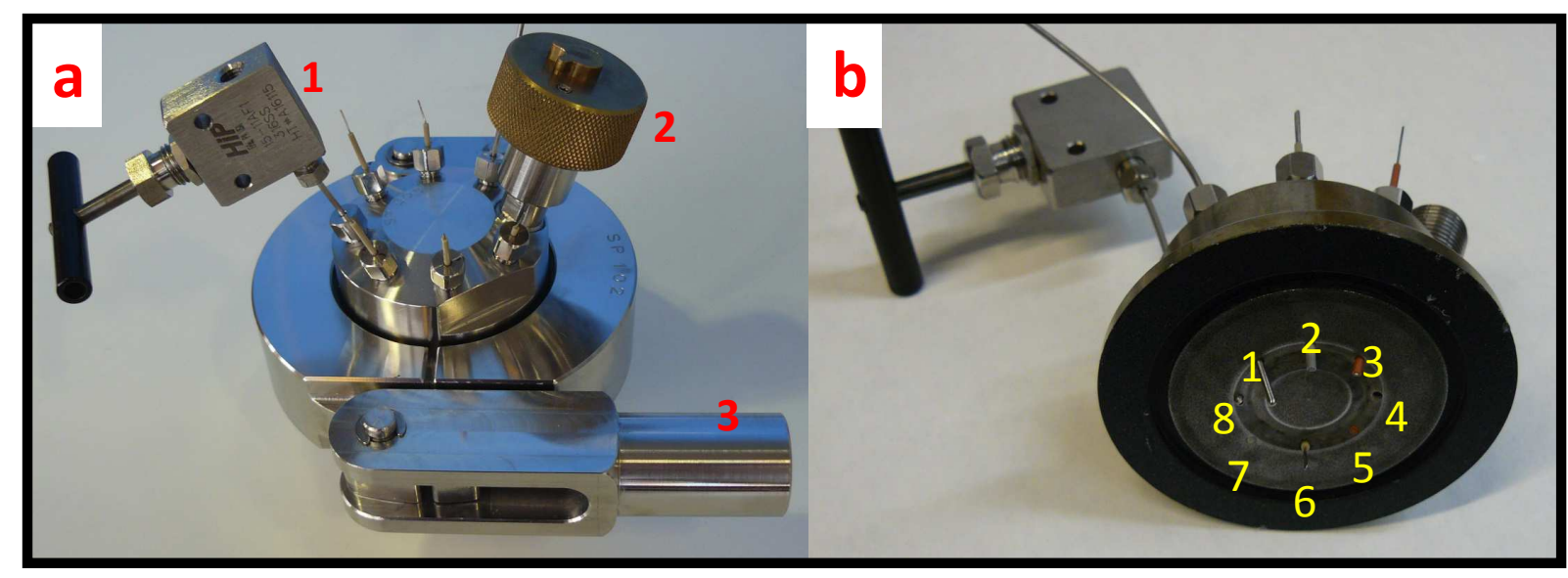

Fig. 1. Images of the high pressure electrochemistry cell. a) Shows a fully assembled cell composed of 2 parts held together with a belt clamp. Visible in the centre is the lid of the cell with the electrode contacts coming through the nuts. This is sealed to the working volume by means of a rubber o-ring and the two parts are held together with the belt clamp (a-3). Also worth noting are the needle valve (a-1) for isolating the cell under pressure and the safety, release valve/clamp key (a2). b) shows the cell lid as assembled for the experiments reported here. Marked are the positions of: 1-the thermocouple; 2-the GC disc electrode; 3-the Pt disc electrode; 4-saftey valve outlet; 5-the Au disc electrode; 6-a Pt wire counter electrode; 7-Pt quasi reference electrode and 8-the inlet tube leading to the needle valve.

The dry electrolytes were weighed into the cell (described elsewhere[13, 22]) in the atmosphere and this was then transferred to the glove box anti-chamber. After $15 \mathrm{~h}$ under nitrogen flow the cell was assembled inside the glove box where the dry acetonitrile co-solvent was added. The fully assembled cell is then attached to the $\mathrm{CO}_{2}$ pump (JASCO PU-1580) and heated to the starting temperature before loading with $\mathrm{CO}_{2}$ at pump rates of 0.3 to $2 \mathrm{ml} \mathrm{min}^{-1}$. Once the cell is filled the solution is allowed to settle for a minimum of 5 min before any measurements are made; when the temperature and pressure was increased the cell was allowed to stabilise for a minimum of $45 \mathrm{~min}$. The starting temperature and pressure for each solution was $306 \mathrm{~K}$ and $15.5 \mathrm{MPa}$.

Electrochemical measurements are performed on an Autolab PGSTAT32 potentiostat with frequency response analyser (Metrohm); using working electrodes of polished gold, platinum and glassy carbon. The counter electrode was a platinum mesh and the quasi-reference electrode was a $0.5 \mathrm{~mm}$ diameter platinum disc. Impedance measurements were made over the frequency range 100 to $1 \mathrm{~Hz}$, using a potential modulation of $\pm 5 \mathrm{mV}$ (rms).

\section{Results}

In earlier studies [20] we investigated the phase behaviour and conductivity for $\mathrm{CO}_{2} / \mathrm{CH}_{3} \mathrm{CN}$ mixtures containing $\left[\mathrm{NBu}_{4}{ }^{n}\right]\left[\mathrm{BF}_{4}\right]$ and several related electrolytes in which the $\left[\mathrm{BF}_{4}\right]^{-}$anion was replaced by fluorinated derivatives of $\left[\mathrm{BPh}_{4}\right]^{-}$(so-called BARF anions) including $\left[\mathrm{B}\left\{3,5-\mathrm{C}_{6} \mathrm{H}_{3}\left(\mathrm{CF}_{3}\right)_{2}\right\}_{4}\right]^{-}$. At elevated temperature and pressure these systems form a single supercritical phase.

In the experiments presented below the conditions were selected so that the system was always in the single phase region. The mole fractions $\left(x_{1}=\mathrm{CO}_{2}, x_{2}=\mathrm{CH}_{3} \mathrm{CN}, x_{3}=\right.$ electrolyte $)$ were dependant on the concentration of electrolyte added and all fell in the range: $x_{1}=0.8872, x_{2}=0.1112, x_{3}=0.0016$ to $x_{1}=0.8885, x_{2}=0.1112, x_{3}=0.0003$. 
For the $\mathrm{CO}_{2} / \mathrm{CH}_{3} \mathrm{CN}$ system our earlier work showed that solutions of reasonably high conductivity (22-26 S cm $\left.{ }^{2} \mathrm{~mol}^{-1}\right)$ could be obtained, particularly in the case of $\left[\mathrm{NBu}_{4}{ }^{n}\right]\left[\mathrm{B}\left\{3,5-\mathrm{C}_{6} \mathrm{H}_{3}\left(\mathrm{CF}_{3}\right)_{2}\right\}_{4}\right]$ and that there was a significant contribution to the conductivity from triple ions in the low dielectric supercritical solvent[20]. In the present studies we have used three different electrolytes, $\left[\mathrm{NBu}_{4}{ }^{n}\right]\left[\mathrm{BF}_{4}\right],\left[\mathrm{NBu}_{4}{ }^{n}\right]\left[\mathrm{B}\left\{3,5-\mathrm{C}_{6} \mathrm{H}_{3}\left(\mathrm{CF}_{3}\right)_{2}\right\}_{4}\right]$ and $\left[\mathrm{NMe}_{4}\right]\left[\mathrm{BF}_{4}\right]$, selected to give different sizes of anion and cation. Each of these ions is approximately spherical, Figure 2

\section{Fluorinated aryl borate}

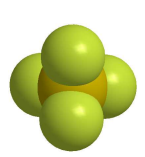

$\left[\mathrm{BF}_{4}\right]^{-} 5.6 \AA$<smiles>F[B-](F)(F)F</smiles>

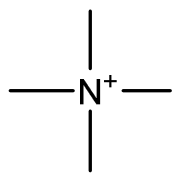

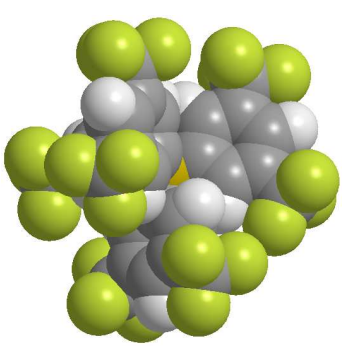

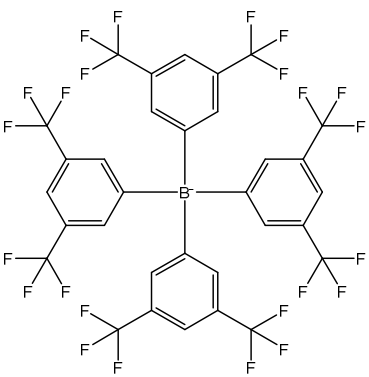

$\left[\mathrm{B}\left\{3,5-\mathrm{C}_{6} \mathrm{H}_{3}\left(\mathrm{CF}_{3}\right)_{2}\right\}_{4}\right]^{-} 15.5 \AA$

\section{Tetraalkylammonium cations}

$\left[\mathrm{NMe}_{4}\right]^{+} 3.94 \AA$

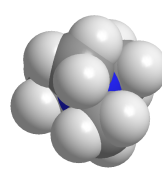

.

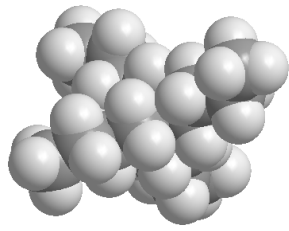

$\left[\mathrm{NBu}_{4}{ }^{n}\right]^{+} 12.0 \AA$

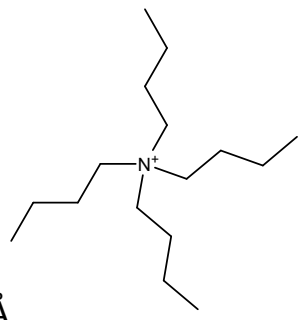

ng electrolytes,

Fig. 2. Space filling representations of the cations and anions used as supporting electrolytes, illustrating their approximate sizes. The dimensions correspond to the estimated diameter across the respective ions based upon van der Waals radii. Dark grey $=\mathrm{C}$, light grey $=\mathrm{H}$, blue $=\mathrm{N}$, yellow $=\mathrm{B}$ and green $=\mathrm{F}$.

For each solution electrochemical impedance measurements were made for a range of potentials where there was little or no background Faradaic electrochemistry. This range was assessed for each electrode substrate by means cyclic voltammetry to limits where the current density was less than 25 $\mu \mathrm{A} \mathrm{cm}^{-2}$.

Figure 3 shows a representative Nyquist plot for data recorded in $\mathrm{scCO}_{2} / \mathrm{CH}_{3} \mathrm{CN}$ with $12.2 \mathrm{mM}$ $\left[\mathrm{NBu}_{4}{ }^{n}\right]\left[\mathrm{BF}_{4}\right]$. Very similar plots were obtained in all cases for the different electrodes, electrolytes and temperatures and pressures studied. 


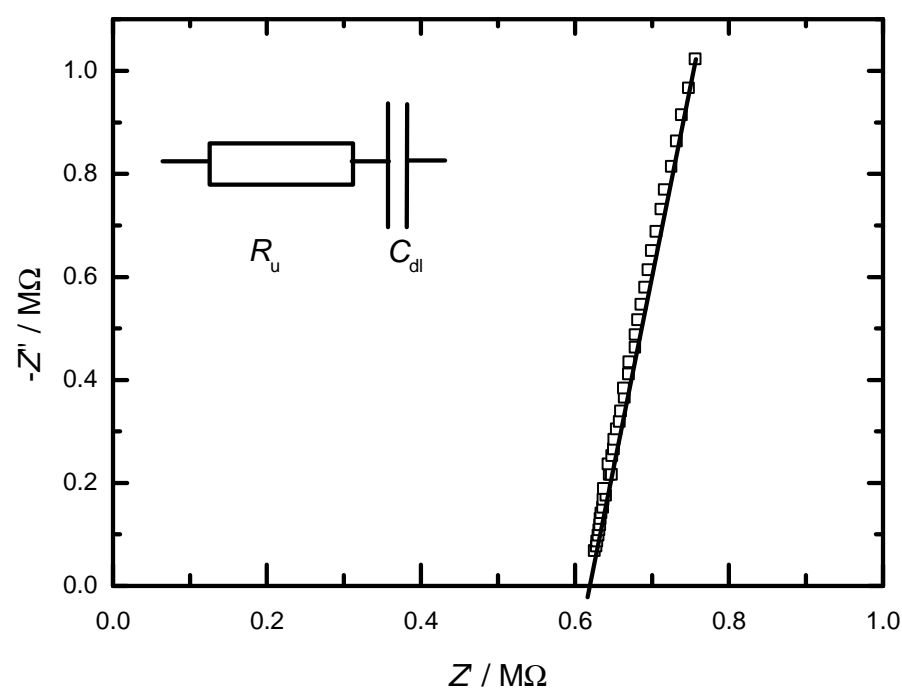

Fig. 3. Typical Nyquist plot for a polished Pt disc ( $0.5 \mathrm{~mm}$ diameter) in $\mathrm{scCO}_{2} / 11 \mathrm{wt} \% \mathrm{CH}_{3} \mathrm{CN}$. The electrolyte is $\left.12.2 \mathrm{mM}^{2} \mathrm{NBu}_{4}{ }^{n}\right]\left[\mathrm{BF}_{4}\right]$ at $310 \mathrm{~K}$ and $17.2 \mathrm{MPa}$. Data recorded at $0.15 \mathrm{~V}$ vs Pt pseudo reference.

The Nyquist plots show a slight deviation from the vertical straight-line response expected for a simple series RC circuit (inset). This type of deviation is not unique to the supercritical fluid electrolytes and is commonly observed for this type of impedance measurement when carried out in aqueous and in non-aqueous solutions. The deviation is often attributed to continuously distributed time constants for charge transfer reactions (where the surface activity of the electrode has local variation) or, where there is no Faradaic process, surface roughness of the electrode. These factors have been reviewed by Orazem and Tribollet [23] who show that the impedance for a 'blocking electrode' (or in this case simply one where only charging and discharging the surface is considered) can be expressed in terms of a constant phase element (CPE) as

$$
Z(\omega)=R+\frac{1}{(j \omega)^{\alpha_{Q}}}
$$

where $R$ is the electrolyte or ohmic resistance, $j$ is the imaginary number $(\sqrt{ }-1), Q$ is the CPE coefficient and $\alpha$ the CPE exponent. For an in depth discussion of the significance of the CPE in this context the reader is directed to the literature[24-28]. The data in Figure 3 give an alpha value which is close to 1 (in this case 0.945 ) and so $Q$ can be approximated to $C$ [29]. The values of solution resistance and electrode interfacial capacitance were then obtained by fitting the impedance data to the simple RC circuit (Figure 3 inset) where $R$ is dominated by the uncompensated solution resistance $R_{\mathrm{u}}$ and $C$ is dominated by the interfacial (double layer) capacitance $C_{\mathrm{dl}}$.

\section{Comparison of electrode materials}


Polished discs of polycrystalline gold, platinum and glassy carbon were used as working electrodes. The applied potential for the electrochemical impedance measurements was varied from $-0.45 \mathrm{~V}$ to $+0.75 \mathrm{~V}$ vs Pt in $200 \mathrm{mV}$ increments (filled points in Figure 4) and then from $+0.65 \mathrm{~V}$ to $-0.35 \mathrm{~V}$ vs Pt in $200 \mathrm{mV}$ increments (open points in Figure 4). The results show little variation in the measured values of $R_{\mathrm{u}}$ and $C_{\mathrm{dl}}$ over time and repeats of these measurements after periods of up to an hour also gave similar values. The measurements were carried out sequentially for the three electrodes mounted together in the cell in the same solution.
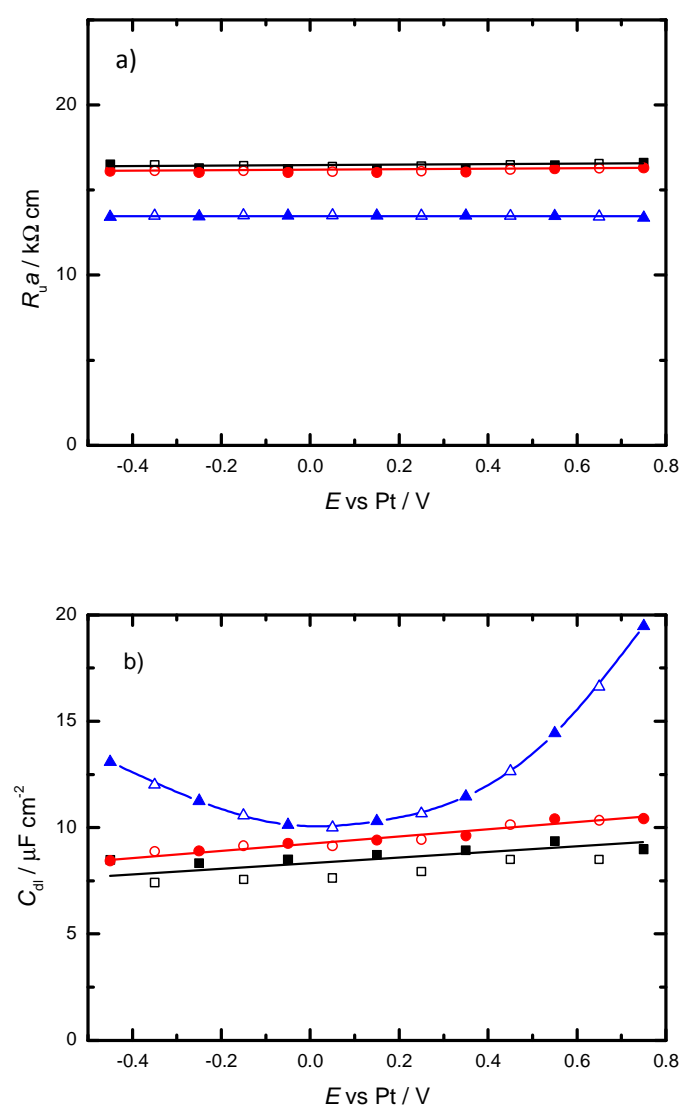

Fig. 4. Comparison of (a) $R_{\mathrm{u}} a$ (where $a$ is the electrode radius) and (b) $C_{\mathrm{dl}}$ for different substrates in $\mathrm{scCO}_{2} / 11$ wt\% $\mathrm{CH}_{3} \mathrm{CN}$ with $12.2 \mathrm{mM}\left[\mathrm{NBu}_{4}{ }^{n}\right]\left[\mathrm{BF}_{4}\right]$ at $306 \mathrm{~K}$ and $15.5 \mathrm{MPa}$. Open symbols represent data taken on the cathodic scan, filled symbols on the anodic scan. Black squares: $0.5 \mathrm{~mm}$ diameter platinum disc; red circles: $0.5 \mathrm{~mm}$ diameter gold disc; blue triangles: $1 \mathrm{~mm}$ diameter glassy carbon disc.

The results shown in Figure 4 (where in Figure 4a we have normalised the uncompensated solution resistance with the electrode radius, $a$ ) are representative of the trends seen in $R_{\mathrm{u}}$ and $C_{\mathrm{dl}}$ for the three electrodes as a function of potential over the full range of temperature (306 to $316 \mathrm{~K}$ ), pressure (15.5 to $20.2 \mathrm{MPa})$ and $\left[\mathrm{NBu}_{4}{ }^{n}\right]\left[\mathrm{BF}_{4}\right]$ concentration $(6.1$ to $30.4 \mathrm{mM})$ studied in this work. Data for the full range of experiments can be found in the Supplementary Information. The Pt and Au electrodes gave very similar values of normalised uncompensated solution resistance $\left(R_{\mathrm{u}} a\right)$ at all potentials and almost identical capacitance-potential profiles. In contrast the glassy carbon disc shows a parabolic dependence of $C_{\mathrm{dl}}$ with respect to potential and slightly lower values for $R_{\mathrm{u}} a$ (see Figure 3a).

The effect of temperature, pressure and electrolyte concentration $R_{\mathrm{u}}$ and $C_{\mathrm{dl}}$. 
There is very little variation in $R_{\mathrm{u}} a$ and $C_{\mathrm{dl}}$ in the isopycnic measurement reported here over the temperature (and associated pressure) range studied and no definite trend with temperature could be inferred from the data (see Supplementary Information)

The effect of the electrolyte concentration was investigated for $\left[\mathrm{NBu}_{4}{ }^{n}\right]\left[\mathrm{BF}_{4}\right]$ over the range from 6.1 to $30.4 \mathrm{mM}$. With increasing concentration the uncompensated solution resistance was found to decrease rapidly up to $18 \mathrm{mM}$ and then to reach a steady value, Figure 5.

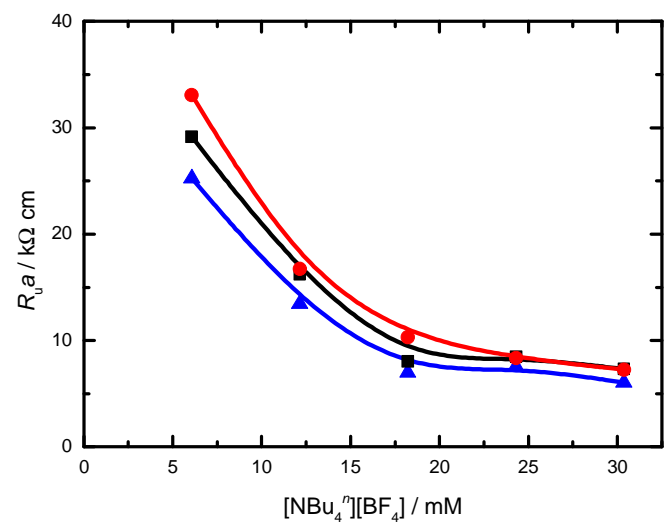

Fig. 5. Effect of electrolyte concentration on $R_{\mathrm{u}} a$. Recorded at $0.5 \mathrm{~mm}$ diameter (a) gold (red circles), (b) platinum (black squares) and (c) $1 \mathrm{~mm}$ diameter glassy carbon (blue triangles) discs in $\mathrm{scCO}_{2} / 11$ wt $\% \mathrm{CH}_{3} \mathrm{CN}$ at $310 \mathrm{~K}$ and $17.2 \mathrm{MPa}$.

Using the Newman equation for the primary resistance, $R$, at an inlaid disc when the counter electrode is at infinity [30] we can write

$$
R=1 / 4 \kappa a
$$

where $\kappa$ is the electrolyte conductivity and $a$ the electrode radius. We can then make estimates of $\kappa$ from the measured $R_{\mathrm{u}}$ assuming $R \approx R_{\mathrm{u}}$. In this case the values for the three electrodes range from 1.1 to $1.7 \mathrm{~S} \mathrm{~cm}^{2} \mathrm{~mol}^{-1}$ and are comparable to the independently measured values reported in our earlier work [20] (2.3 S cm $\mathrm{mol}^{-1}$ for this electrolyte at $20 \mathrm{mM}$ and $328.15 \mathrm{~K}$ and $20.0 \mathrm{MPa}$ ) confirming that the uncompensated solution resistances obtained from the analysis are reasonable.

Figure 6 shows the variation in double layer capacitance with potential for the gold and platinum electrodes at five different concentrations. For the gold electrode the double layer capacitance increases slightly with increasing concentration, roughly doubling in value at all potentials on going from 6.1 and $12.2 \mathrm{mM}$ to 24.3 and $30.4 \mathrm{mM}$ (Figure 6a). In the case of the platinum and glassy carbon electrodes there is no clear trend with concentration (Figure $6 \mathrm{~b}$ and $\mathrm{c}$ ) but for the glassy carbon electrode the capacitances still show an approximately parabolic dependence on potential at all concentrations. 

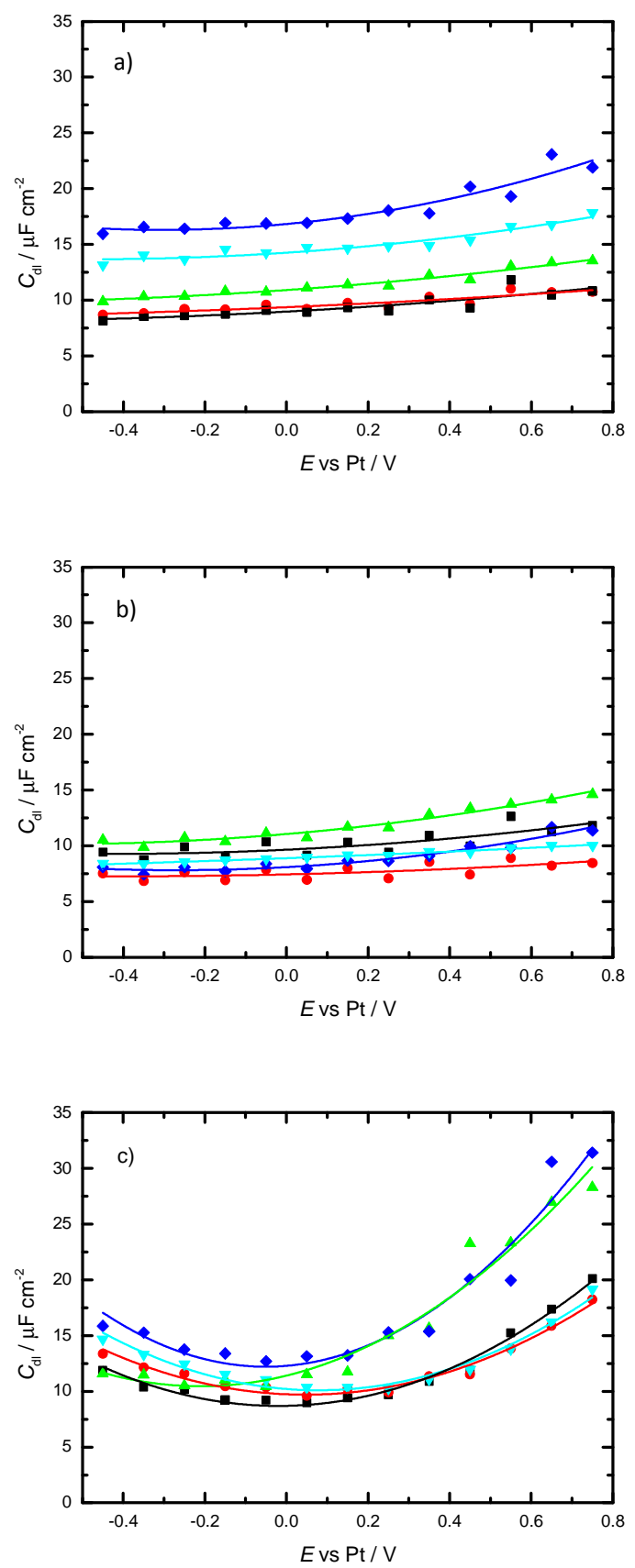

Fig. 6. Variation of interfacial capacitance with increasing concentration of $\left[\mathrm{NBu}_{4}{ }^{\mathrm{n}}\right]\left[\mathrm{BF}_{4}\right]$. Recorded at $0.5 \mathrm{~mm}$ diameter (a) gold, (b) platinum and (c) $1 \mathrm{~mm}$ diameter glassy carbon discs in scCO $/ 11 \mathrm{wt} \%$ $\mathrm{CH}_{3} \mathrm{CN}$ at $310 \mathrm{~K}$ and $17.2 \mathrm{MPa}$. Black squares $6.1 \mathrm{mM}$; red circles $12.2 \mathrm{mM}$; green triangles $18.2 \mathrm{mM}$; blue diamonds $24.3 \mathrm{mM}$; cyan inverted triangles $30.4 \mathrm{mM}$.

A small increase in capacitance with increasing temperature and pressure was observed at all electrodes at anodic potentials (Figure 7) 

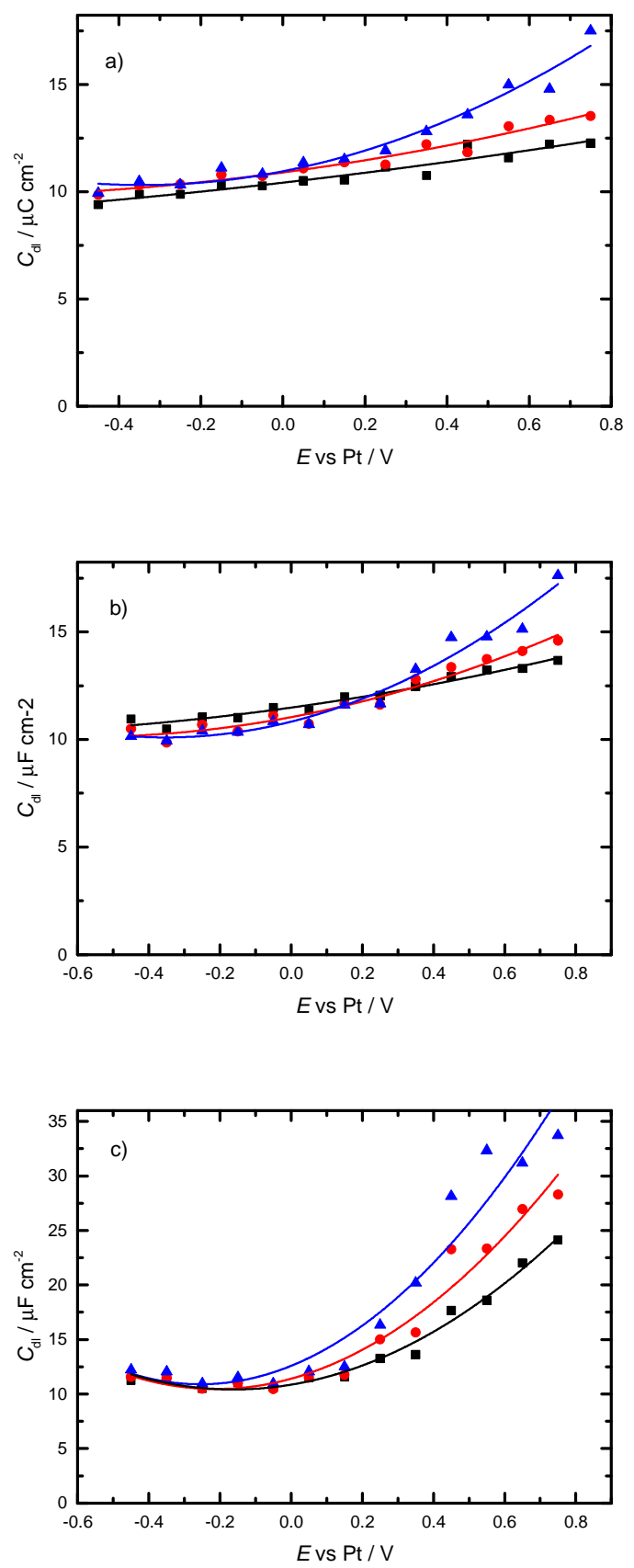

Fig. 7. Variation of interfacial capacitance with increasing temperature. Recorded at $0.5 \mathrm{~mm}$ diameter gold disc (a) $0.5 \mathrm{~mm}$ diameter platinum disc (b) and $1 \mathrm{~mm}$ diameter glassy carbon disc (c) in scCO $\mathrm{sCO}_{2} / 11$ wt\% $\mathrm{CH}_{3} \mathrm{CN}$ with $18.2 \mathrm{mM}\left[\mathrm{NBu}_{4}{ }^{n}\right]\left[\mathrm{BF}_{4}\right]$. Black squares: $306 \mathrm{~K}, 15.5 \mathrm{MPa}$; red circles: $310 \mathrm{~K}$, 17.2 $\mathrm{MPa}$; blue triangles $316 \mathrm{~K}, 20.2 \mathrm{MPa}$.

\section{The effect of anion/cation size on $R_{\mathrm{u}}$ and $C_{\mathrm{d} \text { ॰ }}$}

We have also investigated the effect of changing the size of the anion and cation on the impedance by using $\left[\mathrm{NBu}_{4}{ }^{n}\right]\left[\mathrm{B}\left\{3,5-\mathrm{C}_{6} \mathrm{H}_{3}\left(\mathrm{CF}_{3}\right)_{2}\right\}_{4}\right]$ to have a larger anion and $\left[\mathrm{NMe}_{4}\right]\left[\mathrm{BF}_{4}\right]$ to have a smaller cation (see Figure 2). The results are shown in Table 1 and Figure 8. As expected, based on our earlier work 
[20] the $\left[\mathrm{NBu}_{4}{ }^{n}\right]\left[\mathrm{B}\left\{3,5-\mathrm{C}_{6} \mathrm{H}_{3}\left(\mathrm{CF}_{3}\right)_{2}\right\}_{4}\right]$ electrolyte gives the lowest uncompensated solution resistance (Table 1). $\left[\mathrm{NMe}_{4}\right]\left[\mathrm{BF}_{4}\right]$ gives the highest value and again this is to be expected as the ion pairing for the smaller cation will be greater in the low polarity solvent. Comparing the double layer capacitances at gold and platinum electrodes, Figure $8 \mathrm{a}$ and $\mathrm{b}$, we see that for $\left[\mathrm{NBu}_{4}{ }^{n}\right][\mathrm{B}\{3,5-$ $\left.\left.\mathrm{C}_{6} \mathrm{H}_{3}\left(\mathrm{CF}_{3}\right)_{2}\right\}_{4}\right]$ the value is about one half that for $\left[\mathrm{NBu}_{4}{ }^{n}\right]\left[\mathrm{BF}_{4}\right]$ at all potentials while for $\left[\mathrm{NMe}_{4}\right]\left[\mathrm{BF}_{4}\right]$ the values are similar at anodic potentials but slightly lower than for $\left[\mathrm{NBu}_{4}{ }^{n}\right]\left[\mathrm{BF}_{4}\right]$ at cathodic potentials. For glassy carbon, Figure 8c, the double layer capacitances are approximately parabolic with potential for all three electrolytes and very similar at the cathodic limit $(-0.45 \mathrm{~V})$ becoming separate with $\left[\mathrm{NBu}_{4}{ }^{n}\right]\left[\mathrm{BF}_{4}\right]$ giving the highest capacitance and $\left[\mathrm{NBu}_{4}{ }^{n}\right]\left[\mathrm{B}\left\{3,5-\mathrm{C}_{6} \mathrm{H}_{3}\left(\mathrm{CF}_{3}\right)_{2}\right\}_{4}\right]$ lowest capacitance with increasing anodic potential.

\begin{tabular}{|c|c|}
\hline Electrolyte & $\boldsymbol{R}_{\mathbf{u}} \boldsymbol{a} / \mathbf{k} \boldsymbol{\Omega} \mathbf{~ c m}$ \\
\hline$\left[\mathrm{NBu}_{4}{ }^{n}\right]\left[\mathrm{B}\left\{3,5-\mathrm{C}_{6} \mathrm{H}_{3}\left(\mathrm{CF}_{3}\right)_{2}\right\}_{4}\right]$ & 1.8 \\
\hline$\left[\mathrm{NBu}_{4}{ }^{n}\right]\left[\mathrm{BF}_{4}\right]$ & 8.4 \\
\hline$\left[\mathrm{NMe}_{4}\right]\left[\mathrm{BF}_{4}\right]$ & 64.2 \\
\hline
\end{tabular}

Table 1. Average values of uncompensated solution resistance for $0.5 \mathrm{~mm}$ diameter gold disc at 310 $\mathrm{K}$ and 17.2 MPa and $24.3 \mathrm{mM}$ electrolyte. 

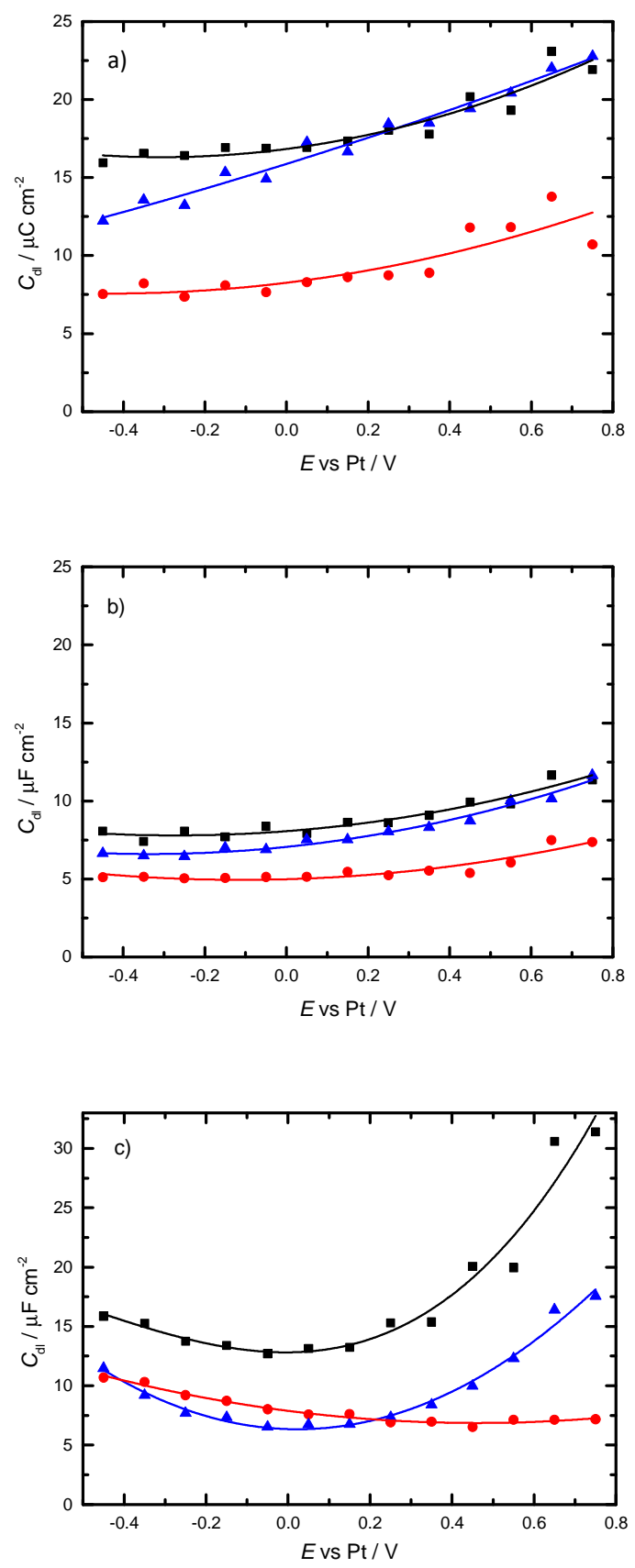

Fig. 8. Variation of interfacial capacitance with ion size. Recorded at $0.5 \mathrm{~mm}$ diameter gold disc (a), $0.5 \mathrm{~mm}$ diameter platinum disc (b) and $1 \mathrm{~mm}$ diameter glassy carbon disc (c) in $\mathrm{scCO}_{2} / 11 \mathrm{wt} \% \mathrm{CH}_{3} \mathrm{CN}$ at $310 \mathrm{~K}$ and $17.2 \mathrm{MPa}$ with $24.3 \mathrm{mM}$ electrolyte. Black squares $\left[\mathrm{NBu}_{4}{ }^{n}\right]\left[\mathrm{BF}_{4}\right]$; red circles $\left[\mathrm{NBu}_{4}{ }^{n}\right]\left[\mathrm{B}\left\{3,5-\mathrm{C}_{6} \mathrm{H}_{3}\left(\mathrm{CF}_{3}\right)_{2}\right\}_{4}\right] ;$ blue triangles $\left[\mathrm{NMe}_{4}\right]\left[\mathrm{BF}_{4}\right]$.

\section{Discussion}

For all the experiments we obtained consistent values for the uncompensated solution resistance, $R_{\mathrm{u}}$, which were consistent with the experimentally determined conductivity for $\left[\mathrm{NBu}_{4}^{n}\right]\left[\mathrm{BF}_{4}\right]$ in $\mathrm{scCO}_{2} / \mathrm{CH}_{3} \mathrm{CN}$ from our earlier work. These values were independent of the electrode potential and 
do not vary significantly for the different electrodes. The uncompensated solution resistances changed with electrolyte concentration (Figure 5) and with the change in choice of electrolyte (Table $1)$ as expected, with $\left[\mathrm{NBu}_{4}{ }^{n}\right]\left[\mathrm{B}\left\{3,5-\mathrm{C}_{6} \mathrm{H}_{3}\left(\mathrm{CF}_{3}\right)_{2}\right\}_{4}\right]$ giving the lowest values for $R_{\mathrm{u}}$. From this we conclude that our impedance data are adequately described by the simple RC circuit used.

Turning to the double layer capacitance data we note that the behaviour for the Au and Pt electrodes is very similar with similar values for $C_{\mathrm{dl}}$ and little dependence on the electrode potential. In contrast the values for glassy carbon show a marked parabolic type potential dependence. We will therefore discuss the two separately starting with the results for Au and Pt.

\section{Double layer capacitance at Au and Pt}

For $\mathrm{Au}$ and $\mathrm{Pt}$ the double layer capacitance data for $\left[\mathrm{NBu}_{4}{ }_{4}\right]\left[\mathrm{BF}_{4}\right]$ show little dependence on the electrode potential (figures 4 and 6) and no clear trends with the concentration (figure 6). Our capacitance values are very similar to those reported by Fawcett's group for tetraalkylammonium perchlorates in propylene carbonate at mercury [31] and for tetraethylammonium perchlorate in acetonitrile at platinum[32], and by Gambert and Baumgärtel for tetraalkylammonium perchlorates at mercury in acetonitrile [33] both in terms of the magnitude of the capacitance and the potential dependence. The results for tetrabutylammonium tetrafluoroborate are consistent with a simple Helmholtz parallel plate model comprising a single layer of $\left[\mathrm{NBu}_{4}^{n}\right]^{+}$, and possibly acetonitrile, at the electrode surface. For a double layer capacitance of around $10 \mu \mathrm{F} \mathrm{cm}^{-2}$, as seen here, if we assume that the value for the dielectric constant, $\varepsilon$, in this Helmholtz layer is 3.2 [31] then we get an estimate for the Helmholtz layer thickness of $0.28 \mathrm{~nm}$ which is comparable to the dimensions of the ions when we take into account the fact that the $\left[\mathrm{NBu}_{4}^{n}\right]^{+}$ion can distort at the metal surface[31]. Our results are consistent with the formation of a Helmholtz layer at the metal surface populated by $\left[\mathrm{NBu}_{4}^{n}\right]^{+}$over the whole potential range investigated suggesting that the potential of zero charge is more anodic than 0.8 V vs. Pt.

Our experiments were conducted at constant density. As the temperature is increased we see evidence for some potential dependence in $C_{\mathrm{dl}}$ at more anodic potentials (figure 7). The effect is small but may reflect the effects of electrostriction [34] and expulsion of solvent (presumably the more polar $\mathrm{CH}_{3} \mathrm{CN}$ rather than $\mathrm{CO}_{2}$ ) from the interface at higher temperature.

Finally we also looked at the effects of changing anion and cation (figure 8). Here we see some effects on $C_{\mathrm{dl}}$ but they are not very large and, because in this case the data come for different experiments, there is greater variability and the results should be interpreted with caution. Broadly for $\mathrm{Au}$ and $\mathrm{Pt}$ we find that the double layer capacitances are very similar for $\left[\mathrm{NBu}_{4}{ }_{4}\right]\left[\mathrm{BF}_{4}\right]$ and $\left[\mathrm{NMe}_{4}\right]\left[\mathrm{BF}_{4}\right]$. In contrast the values for $\left[\mathrm{NBu}_{4}{ }^{n}\right]\left[\mathrm{B}\left\{3,5-\mathrm{C}_{6} \mathrm{H}_{3}\left(\mathrm{CF}_{3}\right)_{2}\right\}_{4}\right]$ are smaller, particularly at anodic potentials consistent with the effect of the presence of a larger anion.

Overall these results are consistent with our earlier work on the electrochemistry of decamethyl ferrocene [35] and electrodeposition of copper [14] and silver [15] in $\mathrm{scCO}_{2} / \mathrm{CH}_{3} \mathrm{CN}$ where we see the expected type of voltammetric behaviour consistent with the major part of the applied potential being dropped at the electrode surface and available to drive the electron transfer kinetics.

\section{Double Layer Capacitance at Glassy Carbon}


We now turn to the double layer capacitance results for glassy carbon. In this case we see a marked potential dependence with a minimum at around $0 \mathrm{~V}$ vs Pt. The capacitance at this minimum is comparable to that at $\mathrm{Au}$ and $\mathrm{Pt}$, around $10 \mu \mathrm{F} \mathrm{cm}^{-2}$. These results were checked using a second glassy carbon electrode and found to be consistent. Our results for glassy carbon are similar to those reported by Kim et al. [36]for glassy carbon in propylene carbonate containing $0.5 \mathrm{M}\left[\mathrm{NBu}_{4}{ }_{4}\right]\left[\mathrm{BF}_{4}\right]$. For carbon electrodes, including glassy carbon, the density of states near the Fermi level is significantly lower than that for Au or Pt [37] and this affects the double layer capacitance. For example early work on pyrolytic graphite and glassy carbon electrodes in aqueous $\mathrm{NaF}$ electrolytes shows similar behaviour[38, 39]. This approximately parabolic potential dependence was explained by Gerischer in terms of the low density of states and the resulting contribution from the space charge layer within the carbon electrode [40] and has recently been investigated using DFT by Luque and Schmickler[41].

\section{Conclusions}

We have investigated the electrochemical impedance at $\mathrm{Au}, \mathrm{Pt}$ and glassy carbon electrodes in $\mathrm{scCO}_{2} /$ $11 \mathrm{wt} \% \mathrm{CH}_{3} \mathrm{CN}$ in solutions of constant density between $306 \mathrm{~K}, 15.5 \mathrm{MPa}$ and $316 \mathrm{~K}, 20.2 \mathrm{MPa}$ over the potential range -0.45 to $+0.75 \mathrm{~V}$ vs. Pt. We find that the data can be adequately described by a simple RC equivalent circuit where the uncompensated solution resistance is consistent with earlier measurements for the conductivity of these electrolytes. We find the resulting values for the double layer capacitance can be described by a simple Helmholtz layer model for Au and Pt and that the behaviour is very similar to that found for similar electrolytes in non-aqueous solvents such as propylene carbonate. For glassy carbon the results for the double layer capacitance show a parabolic like potential dependence which we attribute to the lower density of states near the Fermi level and the space charge contribution to the measured capacitance; again this behaviour is consistent with that found for glassy carbon electrodes in propylene carbonate solutions.

\section{Acknowledgements}

This work is part of the Supercritical Fluid Electrodeposition project (www.scfed.net) which is a multidisciplinary collaboration of British universities investigating the fundamental and applied aspects of supercritical fluids funding by a Programme Grant from the EPSRC (EP/I013394/1). PNB gratefully acknowledges receipt of a Wolfson Research Merit Award.

\section{References}

[1] W.R. Fawcett, Fifty years of studies of double layer effects in electrode kinetics-a personal view, J. Solid State Electrochem. 15 (2011) 1347-58.

[2] B.B. Damaskin, O.A. Petrii, Historical development of theories of the electrochemical double layer, J. Solid State Electrochem. 15 (2011) 1317-34.

[3] A.G. Volkov, D.W. Deamer, D.L. Tanelian, V.S. Markin, Electrical double layers at the oil/water interface, Prog. Surf. Sci. 53 (1996) 1-134. 
[4] Z. Samec, Dynamic electrochemistry at the interface between two immiscible electrolytes, Electrochim. Acta 84 (2012) 21-8.

[5] M.V. Fedorov, A.A. Kornyshev, Ionic liquids at electrified interfaces, Chem. Rev. 114 (2014) 2978-3036.

[6] S. Baldelli, Surface structure at the ionic liquid-electrified metal interface, Acc. Chem. Res. 41 (2008) 421-31.

[7] S.A. Olsen, D.E. Tallman, Conductivity and voltammetry in liquid and supercritical halogenated solvents Anal. Chem. 68 (1996) 2054-61.

[8] S. Chanfreau, P. Cognet, S. Camy, J.S. Condoret, Electrocarboxylation in supercritical $\mathrm{CO}_{2}$ and $\mathrm{CO}_{2}$-expanded liquids, J. Supercrit. Fluids 46 (2008) 156-62.

[9] R.A. Dombro, G.A. Prentice, M.A. McHugh, Electro-organic synthesis in supercritical organic mixtures, J. Electrochem. Soc. 135 (1988) 2219-23.

[10] N. Sun, Y. Hou, W. Wu, M. Niu, W. Wang, Electro-oxidation of benzyl alcohol to benzaldehyde in supercritical $\mathrm{CO}_{2}$ with ionic liquid, Electrochem. Commun. 28 (2013) 34-6.

[11] A.P. Abbott, C.A. Eardley, Electrochemical reduction of $\mathrm{CO}_{2}$ in a mixed supercritical fluid, J. Phys. Chem. B 104 (2000) 775-9.

[12] G.Y. Zhao, T. Jiang, B.X. Han, Z.H. Li, J.M. Zhang, Z.M. Liu, J. He, W.Z. Wu, Electrochemical reduction of supercritical carbon dioxide in ionic liquid 1-n-butyl-3-methylimidazolium hexafluorophosphate, J. Supercrit. Fluids 32 (2004) 287-91.

[13] K. Jie, S. Wenta, S.M. Howdle, M.W. George, D. Cook, M. Perdjon-Abel, P.N. Bartlett, Z. Wenjian, C. Fei, W. Levason, G. Reid, J. Hyde, J. Wilson, D.C. Smith, K. Mallik, P. Sazio, Electrodeposition of metals from supercritical fluids, Proc. Natl. Acad. Sci. USA 106 (2009) 1476872.

[14] D. Cook, P.N. Bartlett, W. Zhang, W. Levason, G. Reid, J. Ke, W. Su, M.W. George, J. Wilson, D. Smith, K. Mallik, E. Barrett, P. Sazio, The electrodeposition of copper from supercritical $\mathrm{CO}_{2}$ /acetonitrile mixtures and from supercritical trifluoromethane, Phys. Chem. Chem. Phys. 12 (2010) 11744-52.

[15] P.N. Bartlett, M. Perdjon-Abel, D. Cook, G. Reid, W. Levason, F. Cheng, W. Zhang, M.W. George, J. Ke, R. Beanland, J. Sloan, The electrodeposition of silver from supercritical carbon dioxide/acetonitrile, ChemElectroChem 1 (2014) 187-94.

[16] M.A. Mendez, P. Voyame, H.H. Girault, Interfacial Photoreduction of Supercritical $\mathrm{CO}_{2}$ by an Aqueous Catalyst, Angew. Chem. Int. Edit. 50 (2011) 7391-4.

[17] A.P. Abbott, C.A. Eardley, Double layer structure in a supercritical fluid, J. Phys. Chem. B 103 (1999) 6157-9.

[18] A.P. Abbott, J.C. Harper, Double-layer studies in solutions of low relative permittivity, J. Chem. Soc. Faraday Trans. 93 (1997) 3981-4. 
[19] A.P. Abbott, J.C. Harper, Double layer capacitance and conductivity studies of long chain quaternary ammonium electrolytes in supercritical carbon dioxide, Phys. Chem. Chem. Phys. 1 (1999) $839-41$.

[20] P.N. Bartlett, D.C. Cook, M.W. George, J. Ke, W. Levason, G. Reid, W.T. Su, W.J. Zhang, Phase behaviour and conductivity study on multi-component mixtures for electrodeposition in supercritical fluids, Phys. Chem. Chem. Phys. 12 (2010) 492-501.

[21] K.E. Toghill, P. Voyame, D. Momotenko, A.J. Olaya, H.H. Girault, Steady-state macroscale voltammetry in a supercritical carbon dioxide medium, Phys. Chem. Chem. Phys. 15 (2013) 972-8.

[22] P.N. Bartlett, D.A. Cook, M.W. George, A.L. Hector, J. Ke, W. Levason, G. Reid, D.C. Smith, W. Zhang, Electrodeposition from supercritical fluids, Phys. Chem. Chem. Phys. 16 (2014) 9202-19.

[23] M.E. Orazem, B. Tribollet, Electrochemical Impedance Spectroscopy, Wiley, Chichester, (2008).

[24] P. Zoltowski, Comments on the paper 'On the ideal polarisability of electrodes displaying cpetype capacitance dispersion' by A. Sadkowski, J. Electroanal. Chem. 481 (2000) 230-1.

[25] P. Zoltowski, On the electrical capacitance of interfaces exhibiting constant phase element behaviour, J. Electroanal. Chem. 443 (1998) 149-54.

[26] G. Lang, K.E. Heusler, Comments on the ideal polarisability of electrodes displaying cpe-type capacitance dispersion, J. Electroanal. Chem. 481 (2000) 227-9.

[27] A. Sadkowski, On the ideal polarisability of electrodes displaying cpe-type capacitance dispersion, J. Electroanal. Chem. 481 (2000) 222-6.

[28] A. Sadkowski, Response to the 'Comments on the ideal polarisability of electrodes displaying cpe-type capacitance dispersion' by G. Lang, K.E. Heusler, J. Electroanal. Chem. 481 (2000) 232-6.

[29] W.G. Pell, A. Zolfaghari, B.E. Conway, Capacitance of the double-layer at polycrystalline Pt electrodes bearing a surface-oxide film, J. Electroanal. Chem. 532 (2002) 13-23.

[30] J. Newman, Resistance for Flow of Current to a Disk, J. Electrochem. Soc. 113 (1966) 501-2.

[31] W.R. Fawcett, M. Fedurco, M. Opallo, The inhibiting effects of tetraalkylammonium cations on simple heterogeneous electron-transfer reactions in polar aprotic-solvents, J. Phys. Chem. 96 (1992) 9959-64.

[32] N.S. Marinkovic, M. Hecht, J.S. Loring, W.R. Fawcett, A SNIFTERS study of the diffuse double layer at single crystal platinum electrodes in acetonitrile, Electrochim. Acta 41 (1996) 641-51.

[33] R. Gambert, H. Baumgärtel, The influence of cations on the interface between the mercury electrode and non-aqueous $\mathrm{CH}_{3} \mathrm{CN}$, J. Electroanal. Chem. 183 (1985) 315-28.

[34] J.R. McDonald, Theory of the differential capacitance of the double layer in unadsorbed electrolytes, J. Chem. Phys. 22 (1954) 1857-66.

[35] J.A. Branch, D.A. Cook, P.N. Bartlett, Electrochemical studies of decamethylferrocene in supercritical carbon dioxide mixtures Phys. Chem. Chem. Phys. 17 (2015) 261-267. 
[36] I.-T. Kim, M. Egashira, N. Yoshimoto, M. Morita, Effects of electrolytic composition on the electric double-layer capacitance at smooth-surface carbon electrodes in organic media, Electrochim. Acta 55 (2010) 6632-8.

[37] R.L. McCreery, Advanced carbon electrode materials for molecular electrochemistry, Chem. Rev. 108 (2008) 2646-87.

[38] J.P. Randin, E. Yeager, Differential capacitance study on basal plane on stress-annealed pyrolytic graphite, J. Electroanal. Chem. 36 (1972) 257-276.

[39] J.P. Randin, E. Yeager, Differential capacitance study on edge orientation of pyrolytic-graphite and glassy carbon electrodes, J. Electroanal. Chem. 58 (1975) 313-22.

[40] H. Gerischer, An interpretation of the double-layer capacity of graphite electrodes in relation to the density of states at the Fermi level, J. Phys. Chem. 89 (1985) 4249-51.

[41] N.B. Luque, W. Schmickler, The electric double layer on graphite, Electrochim. Acta 71 (2012) $82-5$. 


\title{
Measurements of the double layer capacitance for electrodes in supercritical $\mathrm{CO}_{2} /$ acetonitrile electrolytes.
}

\author{
P. N. Bartlett and D. A. Cook
}

Chemistry, University of Southampton, Southampton, SO17 1BJ, UK

\section{Supplementary Information}

Variation of solution resistance and interfacial capacitance in $\mathrm{scCO}_{2}$ with $11 \mathrm{wt} \% \mathrm{CH}_{3} \mathrm{CN}$. Comparison of different tetraalkyl ammonium electrolytes over a range of concentrations and 3 different temperature/pressure conditions. In each case the quasi-reference electrode was a $0.5 \mathrm{~mm}$ diameter platinum disc and the counter electrode was a platinum grid. The working electrodes used were a $1 \mathrm{~mm}$ diameter glassy carbon disc (blue triangles), a $0.5 \mathrm{~mm}$ diameter platinum disc (black squares) and a $0.5 \mathrm{~mm}$ diameter gold disc (red circles). Impedance measurements were made over the frequency range 100 to $1 \mathrm{~Hz}$, using a potential modulation of $\pm 5 \mathrm{mV}$ (rms). More details can be found in the experimental section. 
Figure S1. $6.1 \mathrm{mM}\left[\mathrm{NBu}_{4}{ }^{n}\right]\left[\mathrm{BF}_{4}\right]$.

A. $306 \mathrm{~K}$ and $15.5 \mathrm{MPa}$.
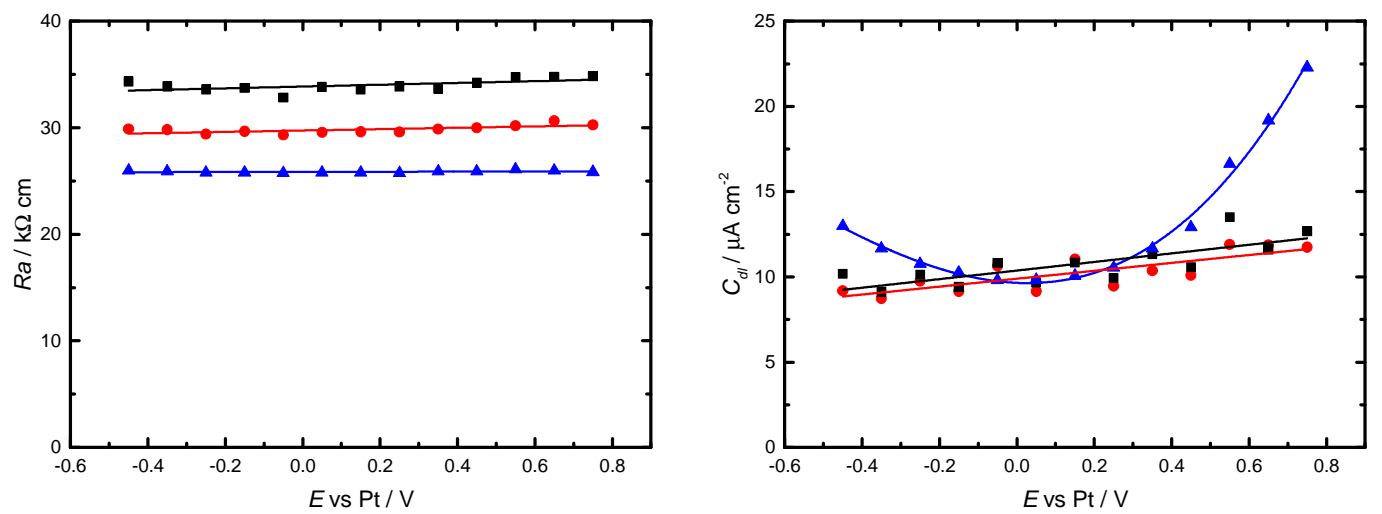

B. $310 \mathrm{~K}$ and $17.2 \mathrm{MPa}$.
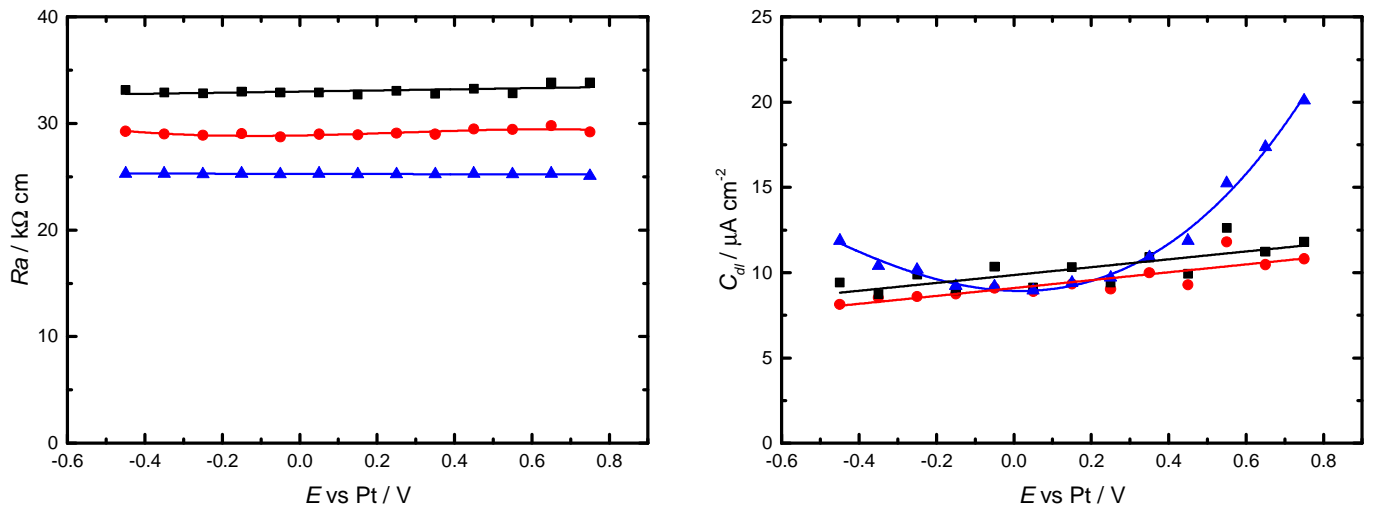

C. $316 \mathrm{~K}$ and $20.2 \mathrm{MPa}$.
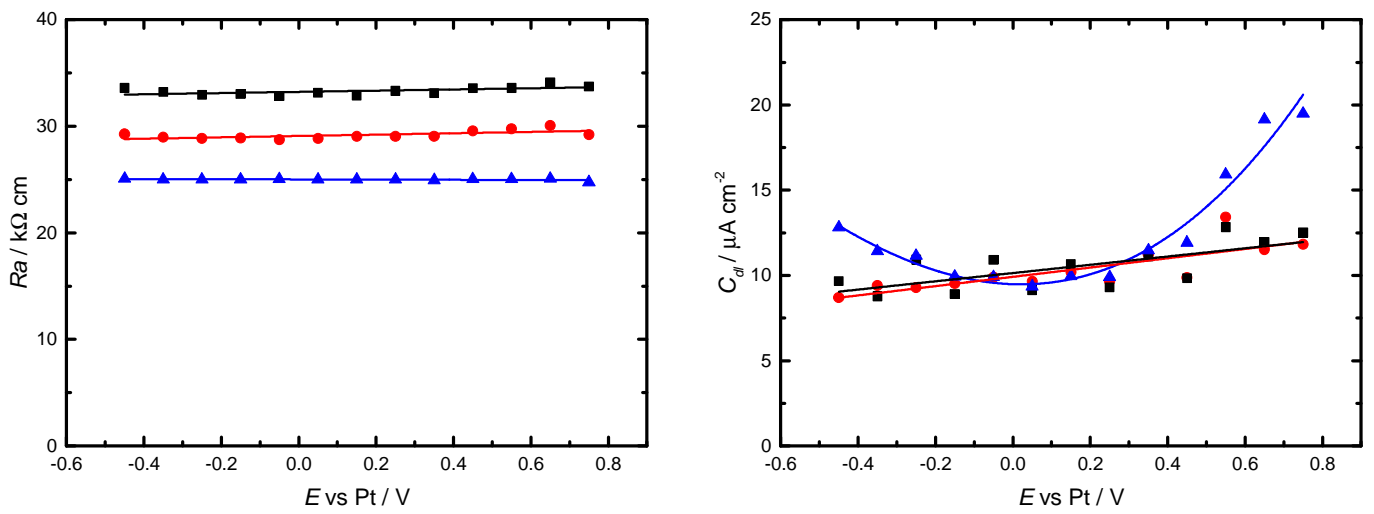
Figure S2. $12.2 \mathrm{mM}\left[\mathrm{NBu}_{4}{ }^{n}\right]\left[\mathrm{BF}_{4}\right]$.

A. $306 \mathrm{~K}$ and $15.5 \mathrm{MPa}$.
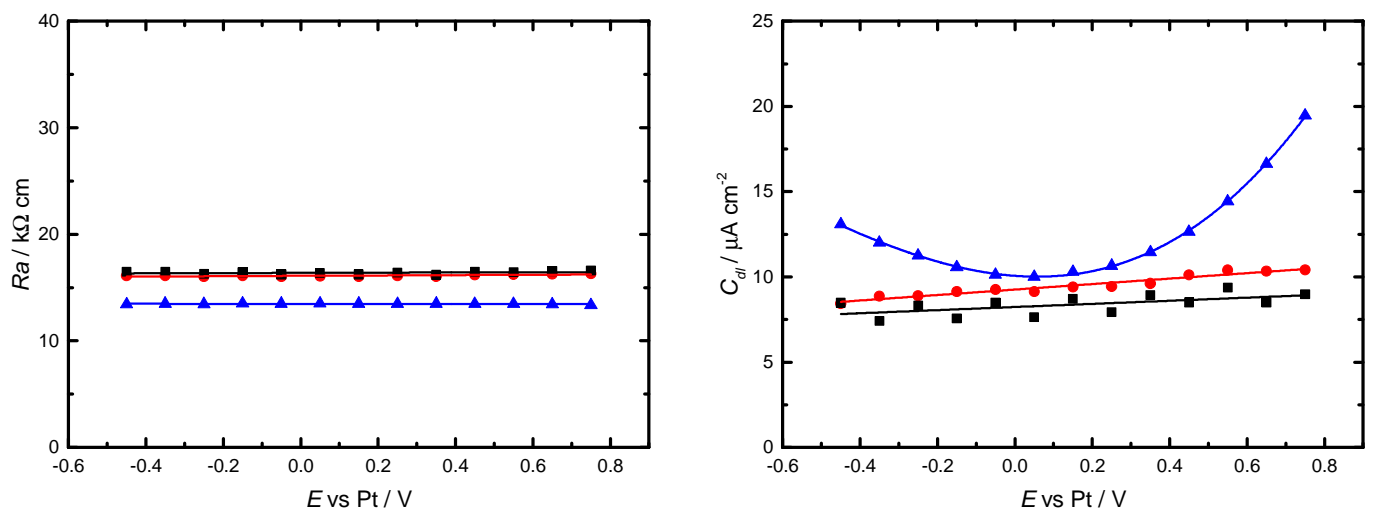

B. $310 \mathrm{~K}$ and $17.2 \mathrm{MPa}$.
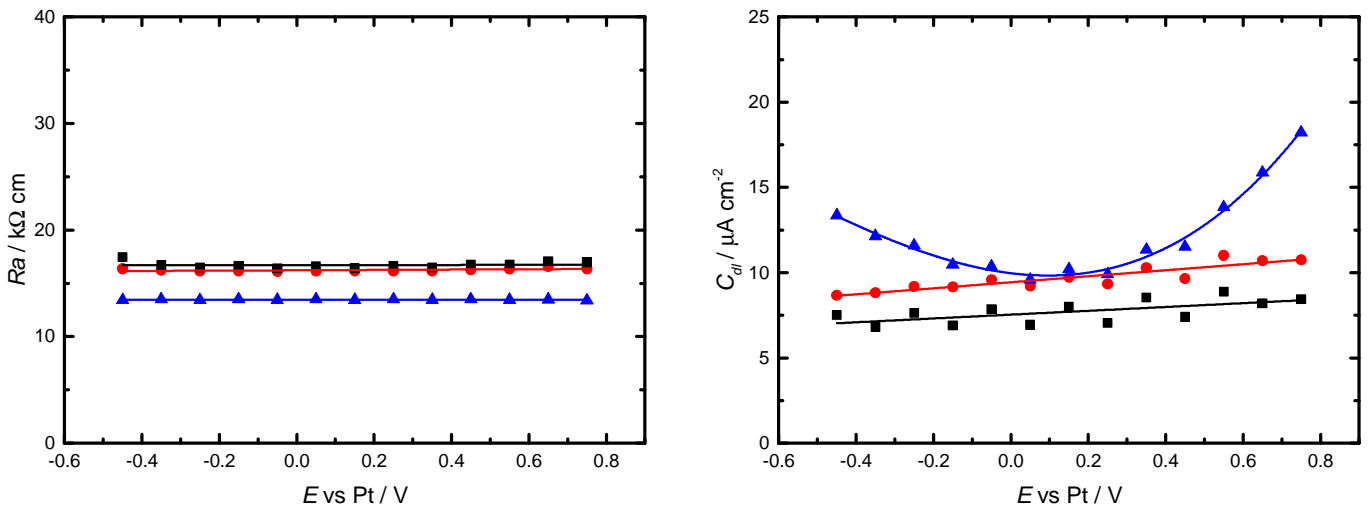

C. $316 \mathrm{~K}$ and $20.2 \mathrm{MPa}$.
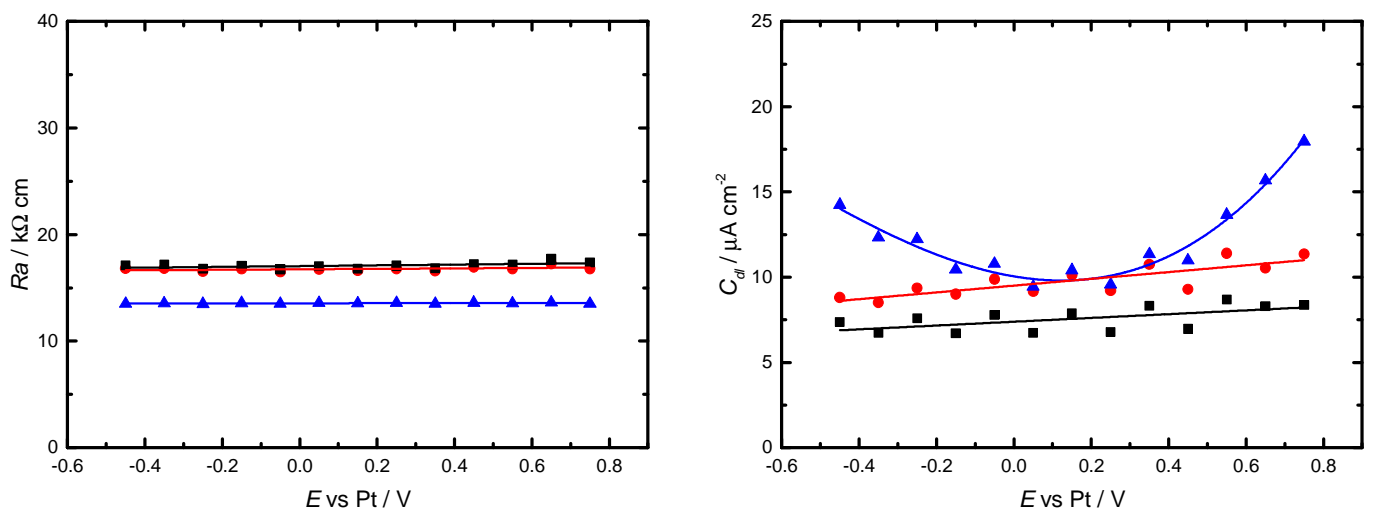
Figure S3. $18.2 \mathrm{mM}\left[\mathrm{NBu}_{4}{ }^{n}\right]\left[\mathrm{BF}_{4}\right]$.

A. $306 \mathrm{~K}$ and $15.5 \mathrm{MPa}$.
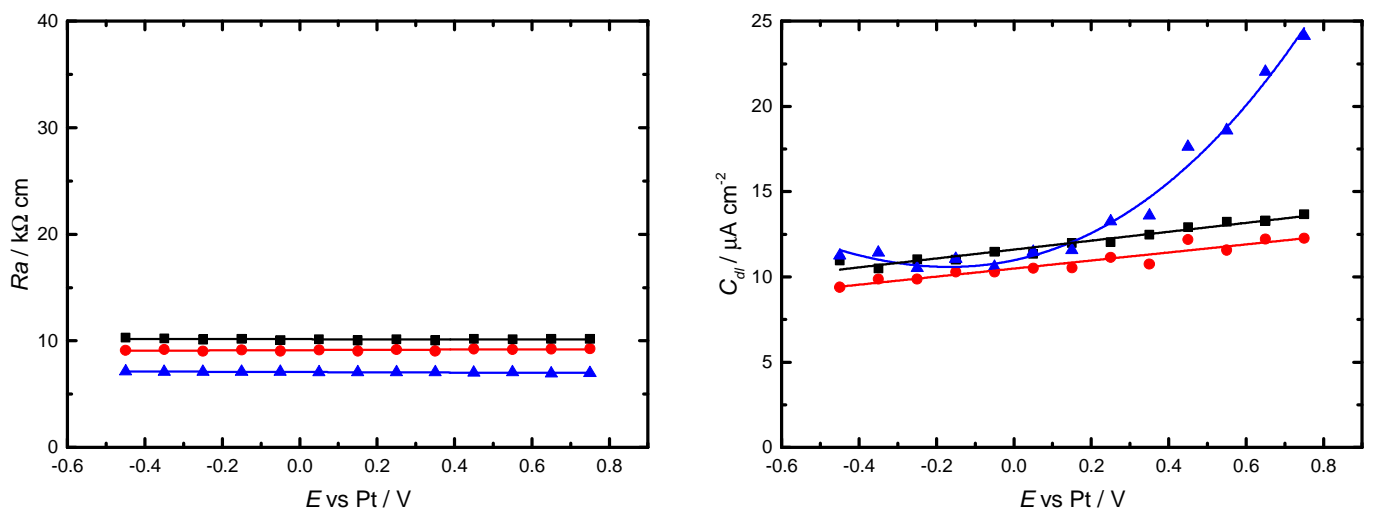

B. $310 \mathrm{~K}$ and $17.2 \mathrm{MPa}$.
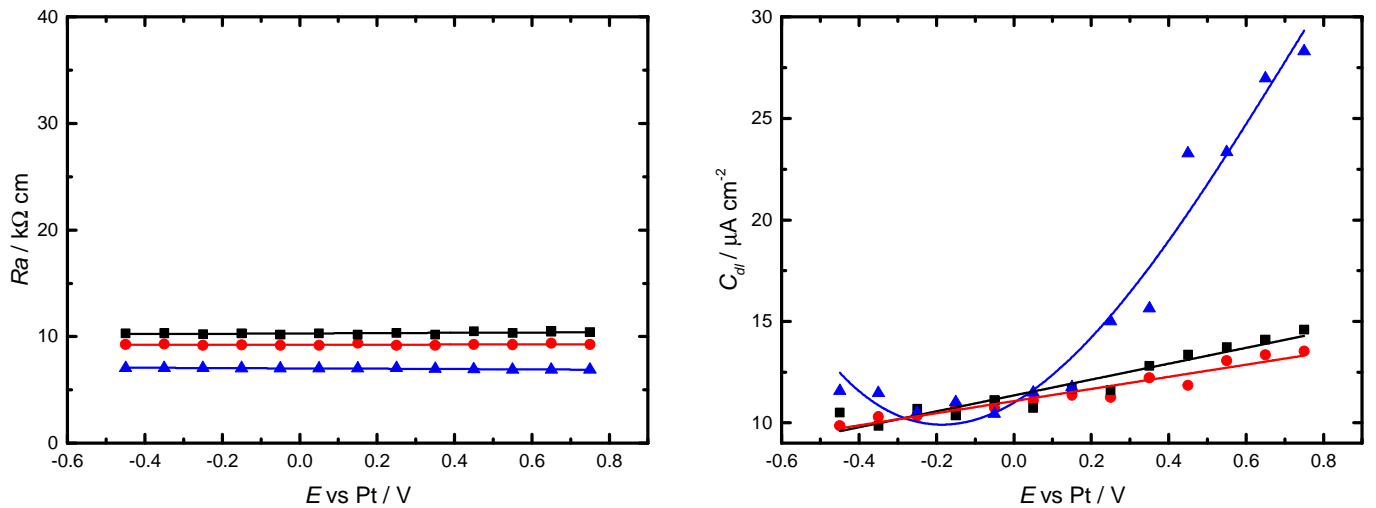

C. $316 \mathrm{~K}$ and $20.2 \mathrm{MPa}$.
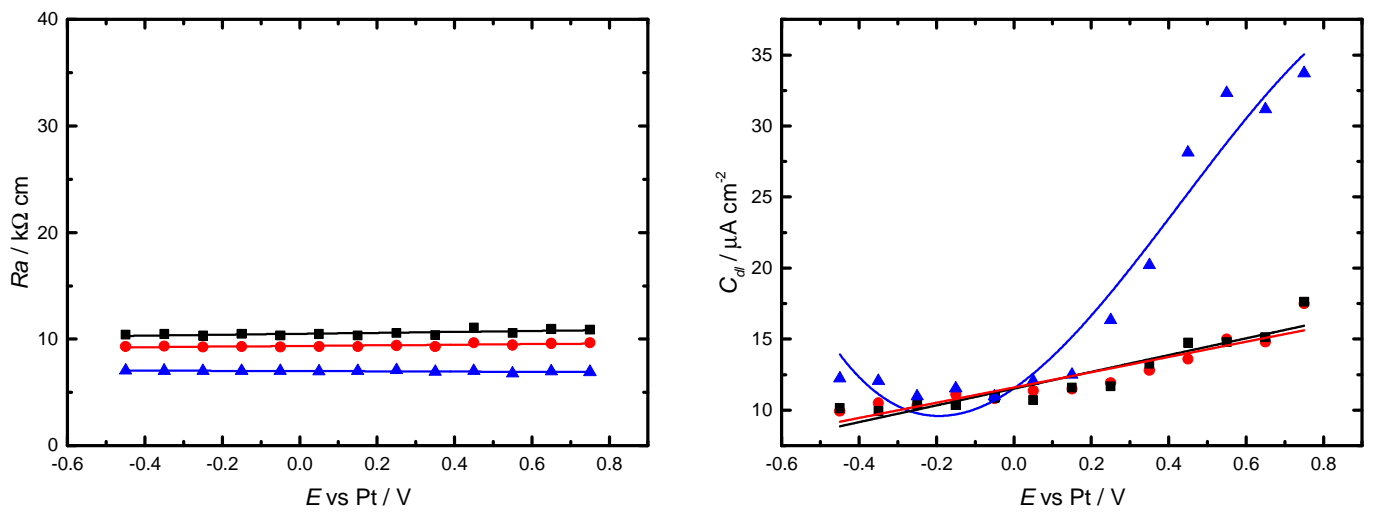
Figure S4. $24.3 \mathrm{mM}\left[\mathrm{NBu}_{4}{ }^{n}\right]\left[\mathrm{BF}_{4}\right]$.

A. $306 \mathrm{~K}$ and $15.5 \mathrm{MPa}$.
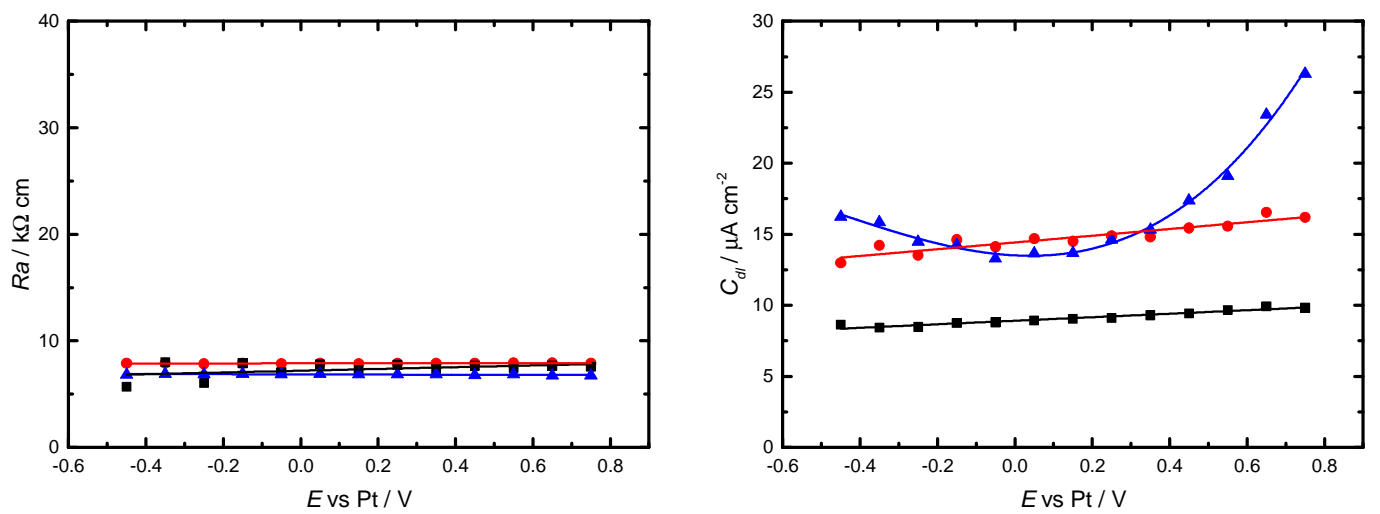

B. $310 \mathrm{~K}$ and $17.2 \mathrm{MPa}$.
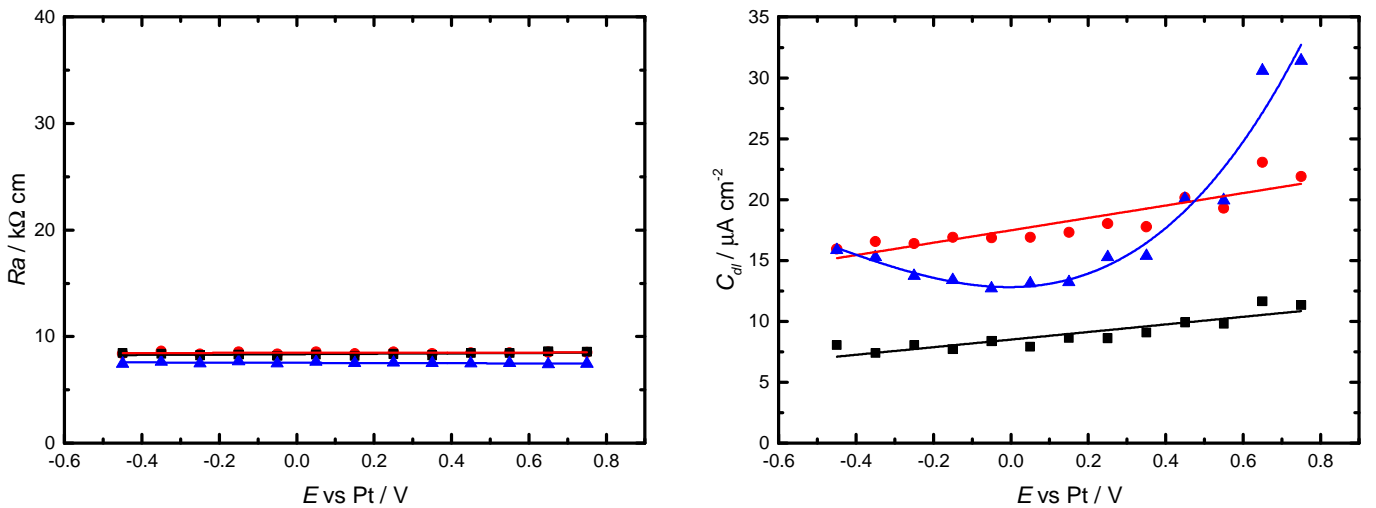

C. $316 \mathrm{~K}$ and $20.2 \mathrm{MPa}$.
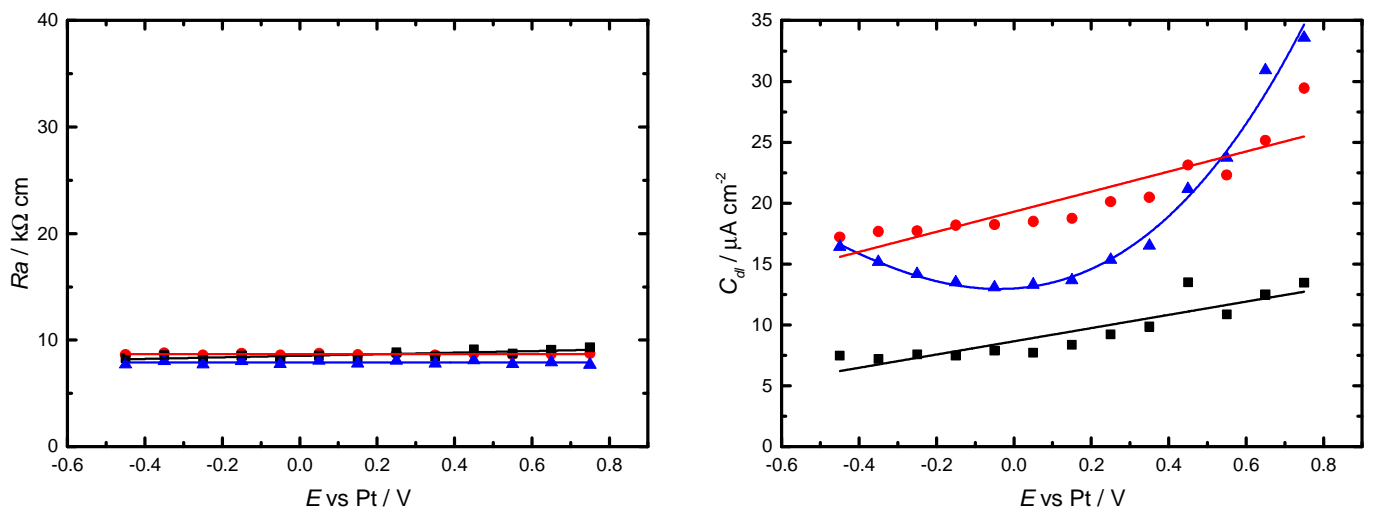
Figure S5. $30.4 \mathrm{mM}\left[\mathrm{NBu}_{4}{ }^{n}\right]\left[\mathrm{BF}_{4}\right]$.

A. $306 \mathrm{~K}$ and $15.5 \mathrm{MPa}$.
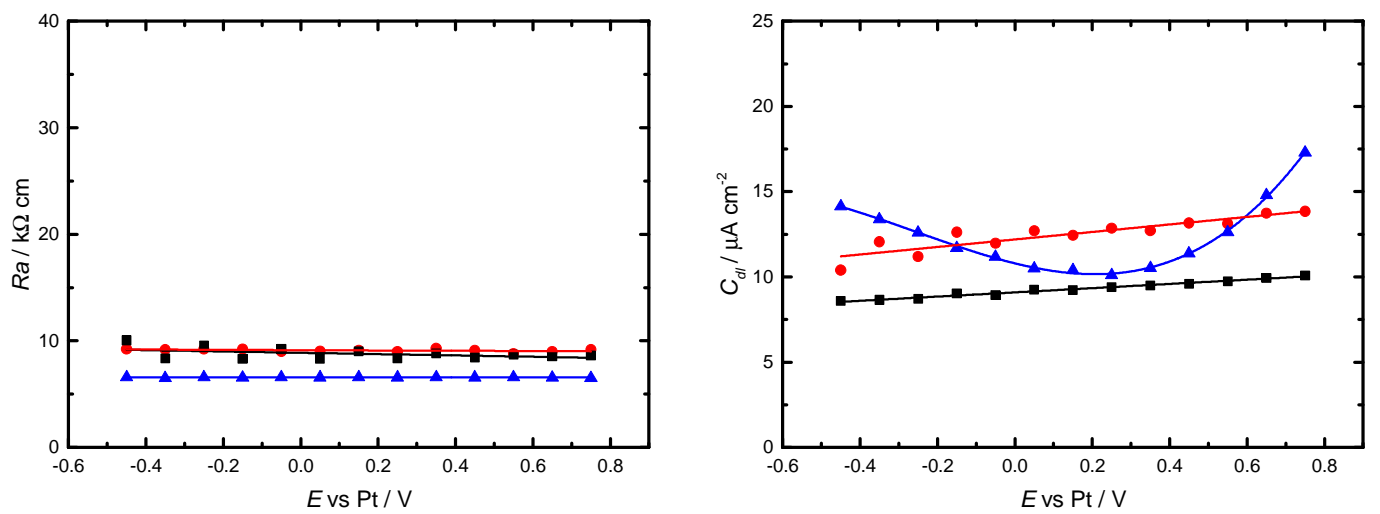

B. $310 \mathrm{~K}$ and $17.2 \mathrm{MPa}$.
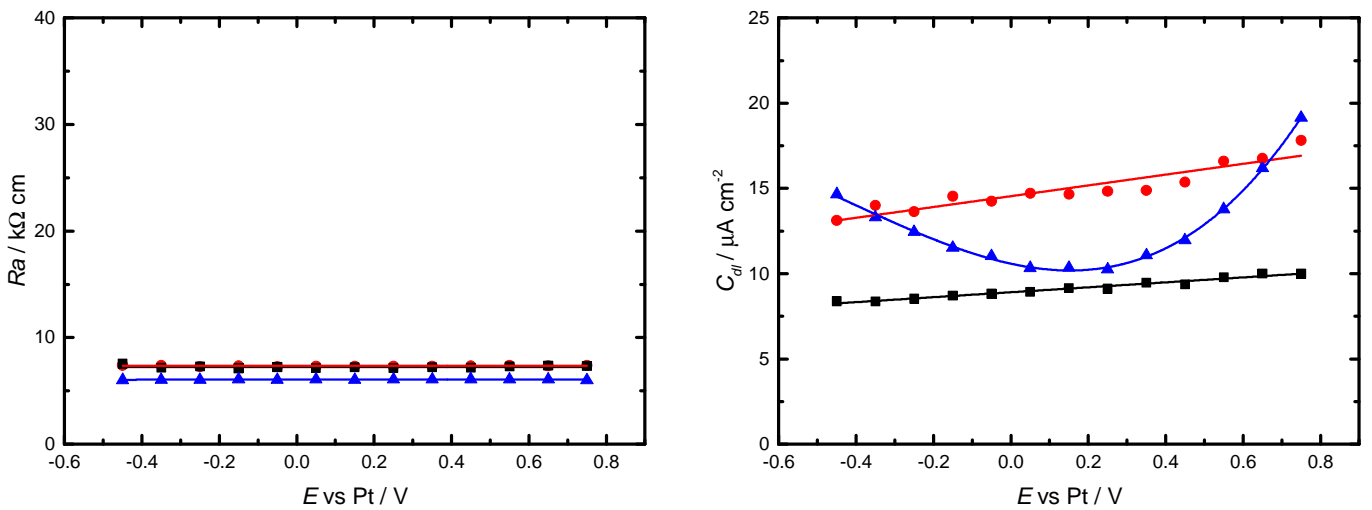

C. $316 \mathrm{~K}$ and $20.2 \mathrm{MPa}$.
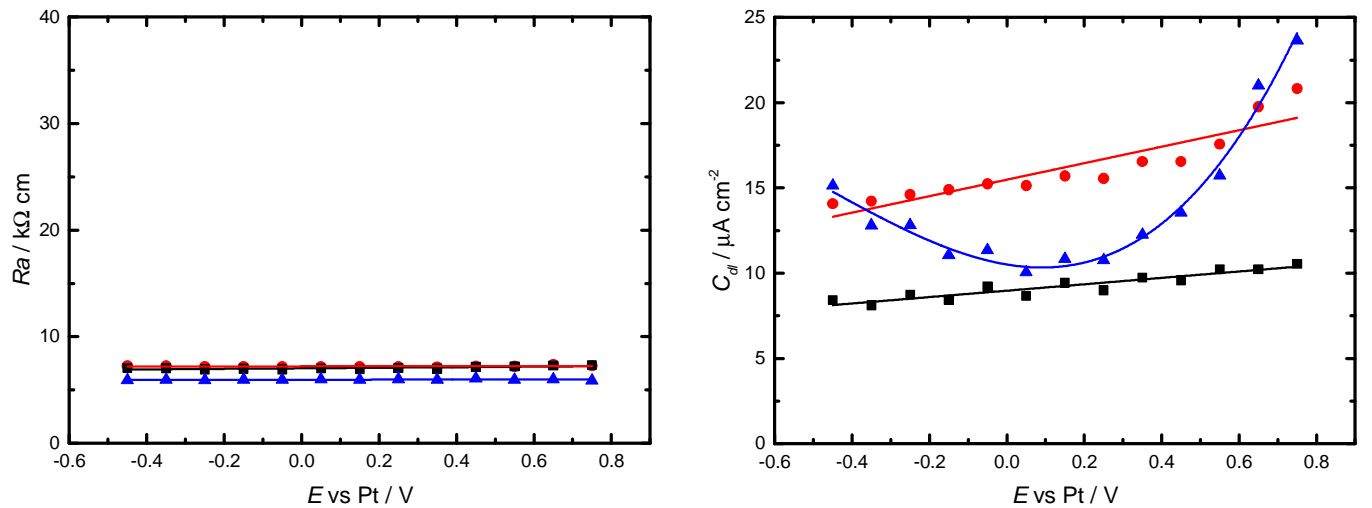
Figure S6. $24.3 \mathrm{mM}\left[\mathrm{NMe}_{4}\right]\left[\mathrm{BF}_{4}\right]$.

A. $306 \mathrm{~K}$ and $15.5 \mathrm{MPa}$.
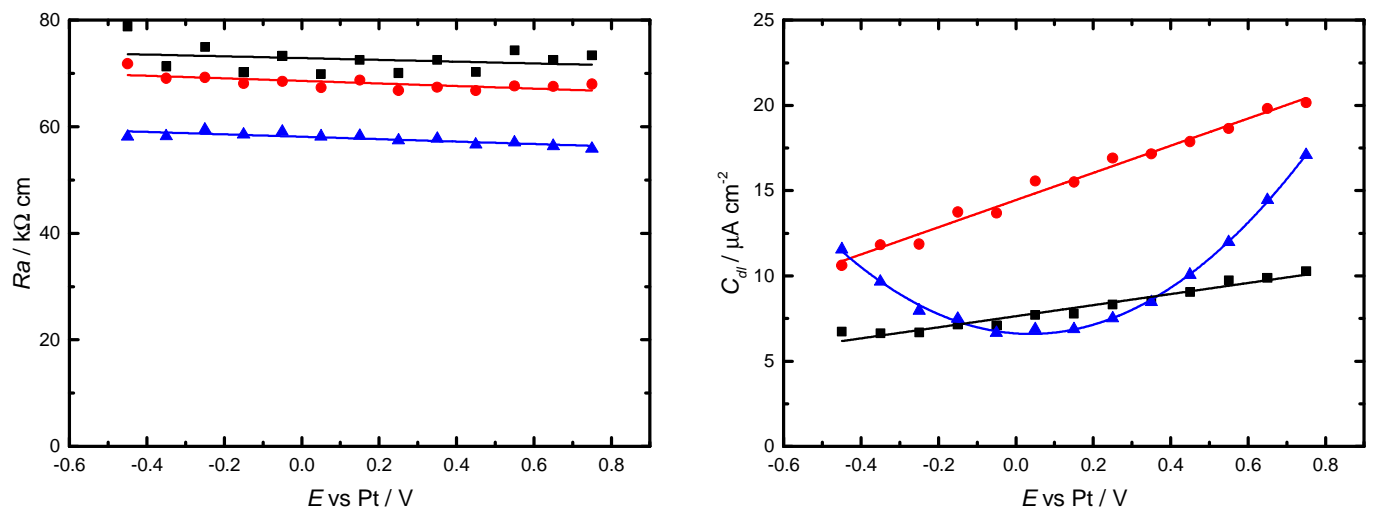

B. $310 \mathrm{~K}$ and $17.2 \mathrm{MPa}$.
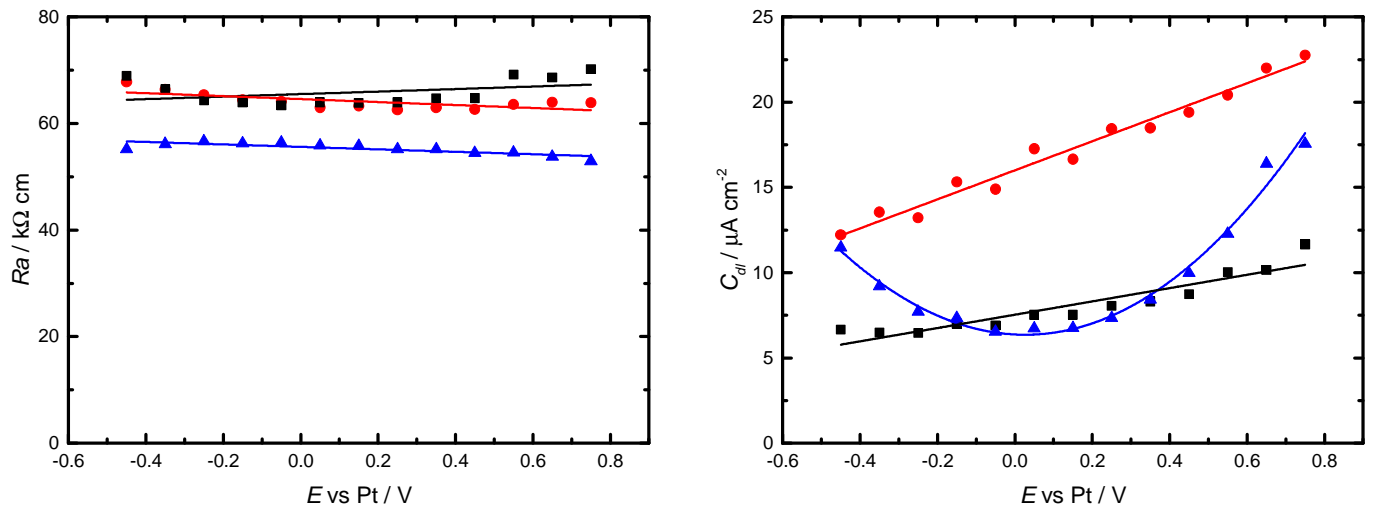

C. $316 \mathrm{~K}$ and $20.2 \mathrm{MPa}$.
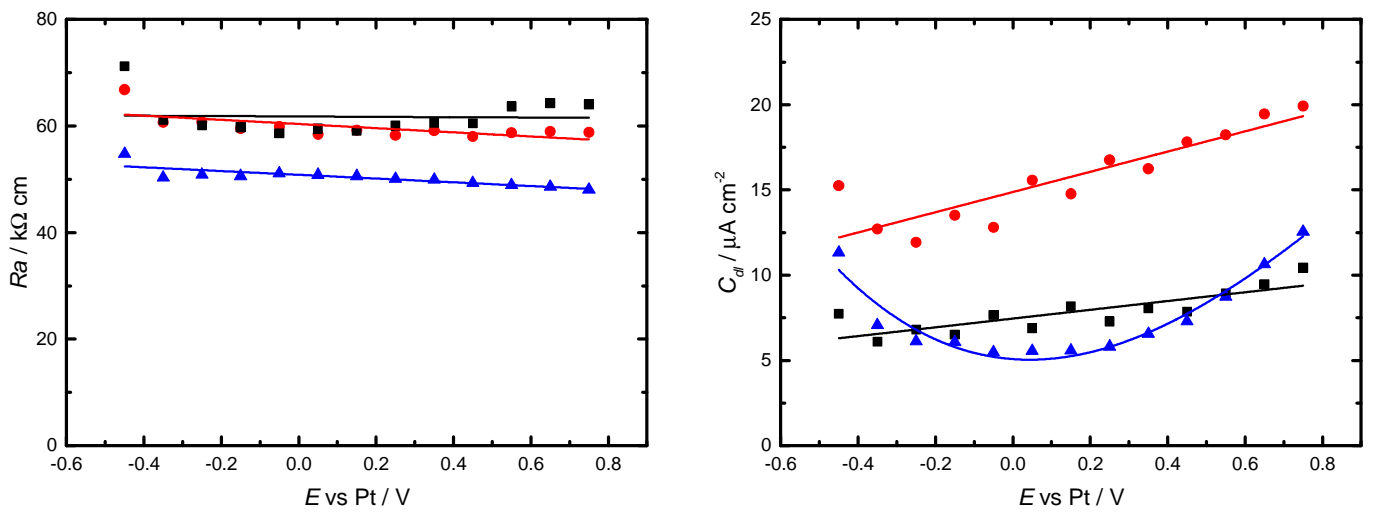
Figure S7. $24.3 \mathrm{mM}\left[\mathrm{NBu}_{4}{ }^{n}\right]\left[\mathrm{B}\left\{3,5-\mathrm{C}_{6} \mathrm{H}_{3}\left(\mathrm{CF}_{3}\right)_{2}\right\}_{4}\right]$.

A. $306 \mathrm{~K}$ and $15.5 \mathrm{MPa}$.
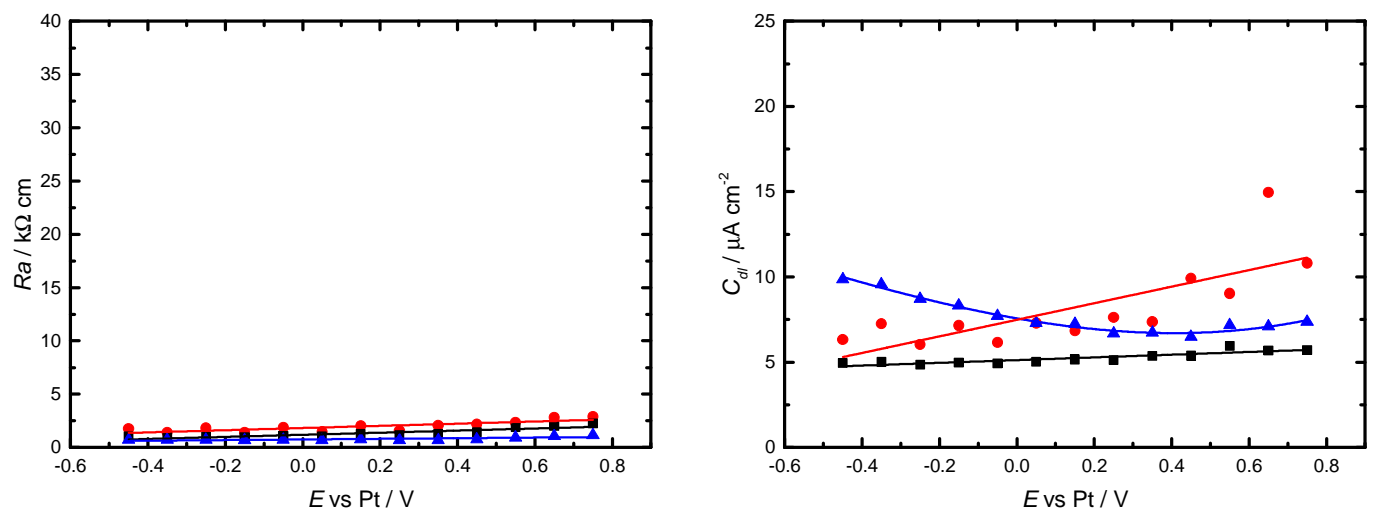

B. $310 \mathrm{~K}$ and $17.2 \mathrm{MPa}$.
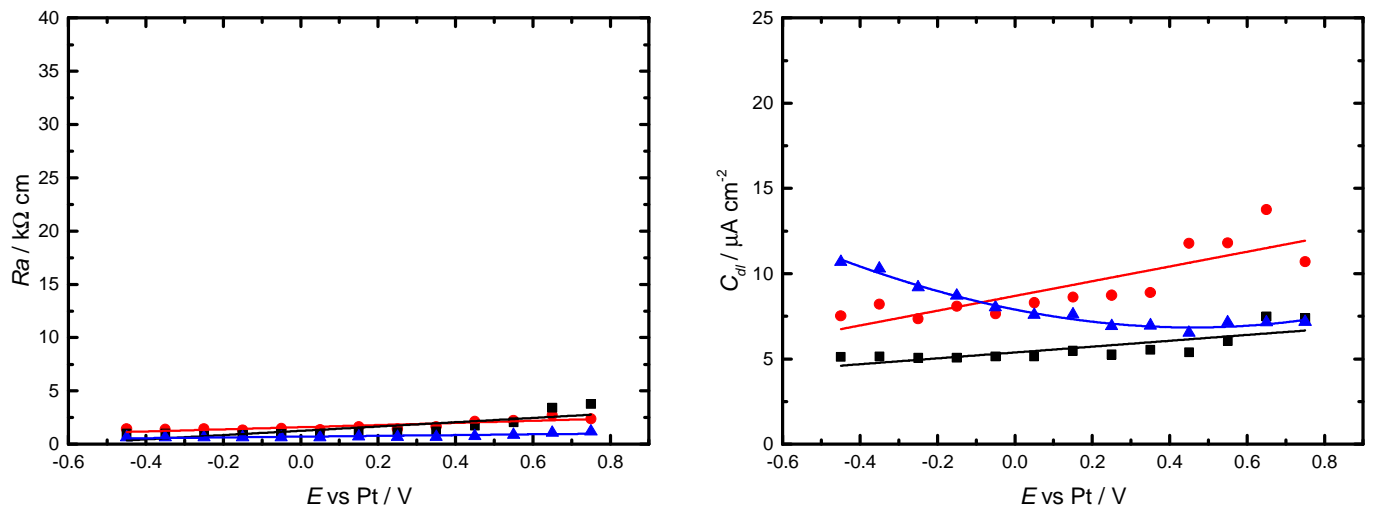

C. $316 \mathrm{~K}$ and $20.2 \mathrm{MPa}$.
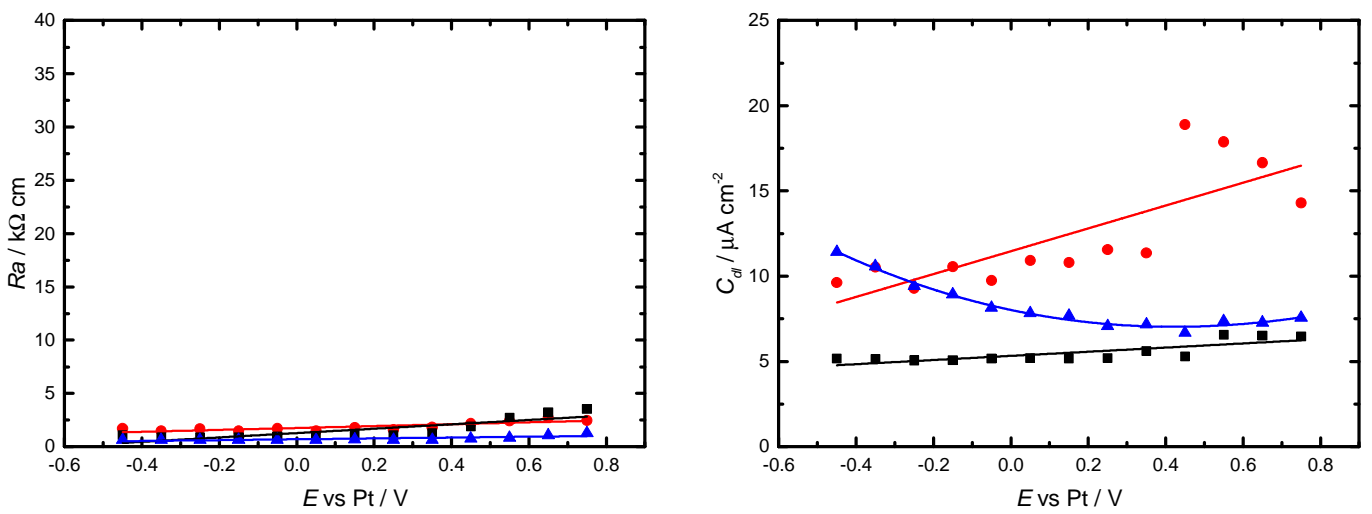